\title{
UNDERSTANDING THE LATEST WAVE AND FUTURE SHAPE OF REGIONAL TRADE AND COOPERATION AGREEMENTS IN ASIA
}

\author{
BISWA N. BHATTACHARYAY \\ CESIFO WORKING PAPER NO. 1856 \\ CATEGORY 7: TRADE POLICY \\ NOVEMBER 2006 \\ Presented at CESifo Venice SUMMER Institute, WORKSHOP ON \\ "UNDERSTANDING THE LATEST WAVE OF REgIONAL TRADE AND COOPERATION \\ AGREEMENTS”, JULY 2006
}

An electronic version of the paper may be downloaded

- from the SSRN website:

www.SSRN.com

- from the RePEc website:

www.RePEc.org

- from the CESifo website: www.CESifo-group.de 


\title{
UNDERSTANDING THE LATEST WAVE AND FUTURE SHAPE OF REGIONAL TRADE AND COOPERATION AGREEMENTS IN ASIA
}

\begin{abstract}
Asia accounts for more than 30\% of world GDP and contributes half of the global growth in recent years. Despite high growth rates, Asia is still facing considerable socio-economic challenges. If Asia is to reemerge as a major power in the global economy and in order for the region to successfully address its own challenges and issues there is a need to make the region's economies more integrated regionally and internationally. Following the recent global trend, Asia witnessed a wave of subregional and bilateral trade agreements. This paper analyzes the recent trends and patterns and nature of regional trade and cooperation agreements (RTCAs) in Asia and associated problems and prospects. It also attempts to understand the latest wave and the future shape of RTCAs and examines if these RTCAs provide the basis for a new Asia-wide cooperation or for the emergence of new regional trade in blocs of several subregional groupings.
\end{abstract}

JEL Code: F1, F2, Q1, Q4, R4.

Keywords: Asia, regional economic cooperation and integration, trade, bilateral and regional trade and cooperation agreements, ASEAN.

\author{
Biswa N. Bhattacharyay \\ Principal Reform Coordination Specialist \\ Office of the President \\ Asian Development Bank \\ Manila, Philippines
}

Principal Reform Coordination Specialist in the Office of the President, Asian Development Bank, Manila. The views expressed in this article are those of the author and do not represent the policy or views of the Asian Development Bank. The usual disclaimers apply. 


\title{
Understanding the Latest Wave and Future Shape of Regional Trade and Cooperation Agreements in Asia
}

\section{Introduction}

\author{
Biswa N. Bhattacharyay ${ }^{2}$
}

Going back in history, some parts of Asia were considered the most economically developed regions in the world. Asia contributed about $58 \%$ of the world's Gross Domestic Product (GDP) in 1500 . Over the next century, this share declined sharply to a meager $27 \%$ in 1902 , and subsequently plunged to a mere $19 \%$ in 1950 as a result of world depression and the devastating effects of World War II. This 19\% share can be considered meager compared to the total population of Asia, which, at that time, accounted for $60 \%$ of the world's population (Madison, 2001). Several studies show that Asia is going to reemerge in a dramatic fashion in the next decades. Radelet et al (1997) projected that by 2025, Asia's share to world GDP will reach 57\%. Goldman Sach's study (Wilson and Purushotaman, 2003) concludes that the GDP of the two largest countries in Asia, namely India and the People's Republic of China, will surpass those of other major industrialized economies of the world in the coming decades.

The past decades have seen a remarkable growth and dynamism in Asia as well as a period of economic and financial turbulence during 1996-1998. The Asian financial crisis of 1997 was a wake-up call for policymakers that regional cooperation and integration can maximize the benefits of globalization while minimizing the costs. In recent years, Asia has been reemerging as the major economic power and the major contributor toward growth in the world economy. Asia accounts for more than $30 \%$ of world GDP and contributes half of the global growth in recent years.

In 2004, the economies of developing Asia grew by 7.8\%-the highest GDP growth since the 1997 crisis, in comparison with 5.3\% world-wide growth. The growth of developing Asia for 2005 is estimated to be slower at $7.4 \%$, but much above the average growth rate in the region since 2000 , and $4.8 \%$ growth of world output in 2005 . Asia is expected to grow at the rate of $7.2 \%$ in 2006 , and, easing to $7.0 \%$ in 2007 , compared to $4.9 \%$ and $4.7 \%$ growth (IMF, 2006) of world output, respectively. The three pillars of Asian economy now are China, India, and, Japan, with expected growth rates of 9.5\%, 7.3\%, and 2.8\%, respectively in 2006 (IMF, 2006). A new dynamics is rising in Asia as a result of the emergence of India and China as major economic powers. Growth projections for developing Asia as a region are heavily influenced by these three major countries. These economies have a combined weight of $66 \%$ of Asian income (Asian Development Bank, 2006).

However, despite high growth rates, Asia is still facing considerable challenges. Major challenges facing developing Asian countries include extreme and persistent poverty together with lack of access to basic services clean water, sanitation, education and heath care,

\footnotetext{
2 Principal Reform Coordination Specialist in the Office of the President, Asian Development Bank, Manila. The views expressed in this article are those of the author and do not represent the policy or views of the Asian Development Bank. The usual disclaimers apply.
} 
increasing income inequalities, epidemic of communicable diseases, high population growth causing overpopulation, high unemployment rate, weak and underdeveloped financial sector, corruption and poor governance, environmental degradation, lack of proper infrastructure, risk arising from fiscal regulatory weakness, policy uncertainty and market distortions and explosive and unplanned urban and suburban growth. Many Asian economies have not witnessed balanced or stable growth and are still vulnerable to external shocks in spite of the build-up of significant foreign reserves in recent years by several countries. The problems of chronic poverty and high unemployment rate together with increasing income inequalities, in particular, may pose a serious threat to the political and economic stability of the region. Two-thirds of the world's poor live in Asia. In 2003, more than $57 \%$ or 1.9 billion (nearly one-third of the world's population) of Asia's population lived on less than $\$ 2$ a day, even though poverty has significantly declined in the last 15 years.

Cross-border initiatives related to trade facilitation and investment promotion can be instrumental in generating jobs, increasing subregional gross national product (GNP), improving intra-subregional trade, and deepening the economic fabric. One of the key instruments for economic development and poverty reduction is regional cooperation and integration (Venables, 2003). Bhattacharyay and De (2005) argued that cross-border infrastructure development in this geographically integrated region in Asia, such as China and India, crucial for promoting greater trade and investment. Consequently, it can attain economic prosperity for poor people as the border region usually contains a large proportion of poor people. China, India and Pakistan have begun to slowly open their borders for trade and human traffic. After more than 44 years, on 7 July 2006, China and India opened famed Silk Road through Nathula Pass, an ancient trading route that once connected China with India, West Asia and Europe. This development becomes very important in the light of opening of Beijing-Tibet rail service. Located some 460 kilometers from Chinese city of Lhasa in Tibet's and 550 kilometers from the Indian coastal city of Kolkata, the Pass will be an important trade route between China and India. It will enhance bilateral trade between the two countries, particularly the border regions and thus help poor traders living in this area.

Therefore, for Asia to reemerge as a major power in the global economy and in order for the region to successfully address its own challenges and issues there is a need to make the region's economies more integrated regionally and internationally. The build-up of significant foreign reserves in recent years has enabled Asia to reduce economic and financial vulnerabilities. In order to be more resilient against external shocks and financial crises, Asia needs to further develop national and regional economies and financial markets through regional cooperation and integration in the areas of trade and investment, money and finance, and key real sectors-particularly on infrastructure.

Regional cooperation and integration in trade, investment, and infrastructure development can foster outward-oriented development and generate economic and social benefits. Integration will bring reduced transaction costs, greater productive infrastructure services, lower trade barriers, faster communication of ideas, goods and services, and rising capital flows. Integration requires a strong political will, not only at the national level, but also at the regional level (Bhattacharyay and De, 2005).

Regional trade and cooperation agreements (RTCA) can be defined as "actions by governments to liberalize or facilitate trade on a regional basis, sometimes through free-trade areas or customs unions". Generally, these agreements outline coverage and depth of preferential trade liberalization, such as tariff reduction as well other preferential treatments. Many countries join the "Free Trade Agreement (FTA) bandwagon" and negotiate bilateral treaties among 
themselves. Many of these are tariff reduction schemes, more commonly called "preferential trade/tariff agreements (PTA)", or bases for free trade zones that prevent countries from severely intruding in each other's economic and social policies. However, in recent years, many countries have realized that the economic integration process includes not only gradual and reciprocal trade liberalization, but also the strengthening of greater economic cooperation between them. Recent RTCAs specify various regulations governing intra-trade, such as regulations on customs administration, safeguard provisions and standards, and a preferential regulatory framework for services trade. The most complex RTCAs could include non-trade related areas, such as regional rules on investment, environment, labor, and competition. ${ }^{3}$

The world has witnessed a recent wave of RTCAs involving both developing and developed countries. These agreements have mushroomed in recent years, particularly since 1990. By July 2005, the WTO (and its predecessor, GATT) had been notified of a total of 330 agreements compared to 130 in January 1955. Of these, 180 are currently in force. Additional RTCAs are believed to be operational but not notified yet. Furthermore, apart from Mongolia, all WTO members are involved in one or more regional trade agreements. ${ }^{4}$

With the unsuccessful World Trade Organization (WTO) talks in Cancun, there is an increasing world-wide trend towards regional cooperation and integration, such as bilateral, sub-regional, and regional preferential trade/tariff agreements such as the European Integration- the expanded European Union (EU), the European Free Trade Association (EFTA); North and Central American integrations- the North American Free Trade Agreement (NAFTA); Central American Free Trade Agreement (CAFTA); The Southern Common Market (MERCOSUR); Asia Integration- The Association of Southeast Asian Nations (ASEAN) Free Trade Area (AFTA); the South Asian Association for Regional cooperation (SAARC); Australia-New Zealand Closer Economic Relations Agreement; the African Integration- The Common Market of Eastern and Southern Africa (COMESA); and the Middle East Integration- Gulf Cooperation Council (GCC) Currency Union in 2010. Table 1 presents information on 33 major RTCAs worldwide and their member countries. Except for the Bay of Bengal Initiative for Multisectoral Technical and Economic Cooperation (BIMSTEC), all these RTCAs are ratified by WTO.

The recent round of WTO negotiations of the Mini-Ministerial meeting in Geneva during June 29 to July 02, 2006 ended in a logjam over the issue of industrialized nations cutting domestic subsidy for agriculture and developing nations reducing tariff on industrial goods. At WTO the developing countries are demanding greater access to the agricultural markets of developed countries while the industrialized nations want the developing countries to open up their markets for services and industrial goods. The talks are stuck because no agreement is in sight on cut in agriculture tariffs and domestic subsidies that developed countries should make so that products from developing countries could enter their markets and compete.

Table 1: Worldwide Trends in Regional Trade and Cooperation Agreements

\begin{tabular}{|l|l|l|}
\hline \multicolumn{1}{|c|}{ RTCA Name } & $\begin{array}{c}\text { Regional Trade and Cooperation } \\
\text { Agreement }\end{array}$ & \multicolumn{1}{c|}{ Member Countries } \\
\hline 1. AFTA & ASEAN Free Trade Area & $\begin{array}{l}\text { Brunei, Darussalam, Cambodia, Indonesia, Laos, } \\
\text { Malaysia, Myanmar, Philippines, Singapore, Thailand, } \\
\text { Vietnam }\end{array}$ \\
\hline
\end{tabular}

3 WTO website, http://www.wto.org/english/tratop_e/region_e/scope_rta_e.htm WTO website, http://www.wto.org/english/thewto_e/whatis_e/tif_e/bey 1 _e.htm 


\begin{tabular}{|c|c|c|}
\hline 2. ASEAN & $\begin{array}{l}\text { Association of South East Asian } \\
\text { Nations }\end{array}$ & $\begin{array}{l}\text { Brunei Darussalam, Cambodia, Indonesia, Laos, } \\
\text { Malaysia, Myanmar, Philippines, Singapore, Thailand, } \\
\text { Vietnam }\end{array}$ \\
\hline 3. BAFTA & Baltic Free-Trade Area & Estonia, Latvia, Lithuania \\
\hline 4. BANGKOK & Bangkok Agreement & $\begin{array}{l}\text { Bangladesh, China, India, Republic of Korea, Laos, } \\
\text { Sri Lanka }\end{array}$ \\
\hline 5. BIMSTEC & $\begin{array}{l}\text { Bay of Bengal Initiative for } \\
\text { Multi-Sectoral Technical and } \\
\text { Economic Cooperation }\end{array}$ & $\begin{array}{l}\text { Bangladesh, Bhutan, India, Myanmar, Nepal, Sri } \\
\text { Lanka, Thailand }\end{array}$ \\
\hline 6. CAN & Andean Community & Bolivia, Colombia, Ecuador, Peru, Venezuela \\
\hline 7. CARICOM & $\begin{array}{l}\text { Caribbean Community and Common } \\
\text { Market }\end{array}$ & $\begin{array}{l}\text { Antigua \& Barbuda, Bahamas, Barbados, Belize, } \\
\text { Dominica, Grenada, Guyana, Haiti, Jamaica, } \\
\text { Monserrat, Trinidad \& Tobago, St. Kitts \& Nevis, St. } \\
\text { Lucia, St. Vincent \& the Grenadines, Surinam }\end{array}$ \\
\hline 8. CACM & Central American Common Market & $\begin{array}{l}\text { Costa Rica, El Salvador, Guatemala, Honduras, } \\
\text { Nicaragua }\end{array}$ \\
\hline 9. CEFTA & $\begin{array}{l}\text { Central European Free Trade } \\
\text { Agreement }\end{array}$ & Bulgaria, Croatia, Romania \\
\hline 10. CEMAC & $\begin{array}{l}\text { Economic and Monetary Community } \\
\text { of Central Africa }\end{array}$ & $\begin{array}{l}\text { Cameroon, Central African Republic, Chad, Congo, } \\
\text { Equatorial Guinea, Gabon }\end{array}$ \\
\hline 11. CER & $\begin{array}{l}\text { Closer Trade Relations Trade } \\
\text { Agreement }\end{array}$ & Australia, New Zealand \\
\hline 12. CIS & $\begin{array}{l}\text { Commonwealth of Independent } \\
\text { States }\end{array}$ & $\begin{array}{l}\text { Azerbaijan, Armenia, Belarus, Georgia, Moldova, } \\
\text { Kazakhstan, Russian Federation, Ukraine, Uzbekistan, } \\
\text { Tajikistan, Kyrgyz Republic }\end{array}$ \\
\hline 13. COMESA & $\begin{array}{l}\text { Common Market for Eastern and } \\
\text { Southern Africa }\end{array}$ & $\begin{array}{l}\text { Angola, Burundi, Comoros, Democratic Republic of } \\
\text { Congo, Djibouti, Egypt, Eritrea, Ethiopia, Kenya, } \\
\text { Madagascar, Malawi, Mauritius, Namibia, Rwanda, } \\
\text { Seychelles, Sudan, Swaziland, Uganda, Zambia, } \\
\text { Zimbabwe }\end{array}$ \\
\hline 14. EAC & East African Cooperation & Kenya, Tanzania, Uganda \\
\hline 15. EAEC & Eurasian Economic Community & $\begin{array}{l}\text { Belarus, Kazakhstan, Kyrgyz Republic, Russian } \\
\text { Federation, Tajikistan }\end{array}$ \\
\hline 16. EC & European Communities & $\begin{array}{l}\text { Austria, Belgium, Cyprus, Czech Republic, Denmark, } \\
\text { Estonia, Finland, France, Germany, Greece, Hungary, } \\
\text { Ireland, Italy, Latvia, Lithuania, Luxembourg, Malta, } \\
\text { Netherlands, Poland, Portugal, Slovak Republic, } \\
\text { Slovenia, Spain, Sweden, United Kingdom }\end{array}$ \\
\hline 17. ECO & Economic Cooperation Organization & $\begin{array}{l}\text { Afghanistan, Azerbaijan, Iran, Kazakhstan, Kyrgyz } \\
\text { Republic, Pakistan, Tajikistan, Turkey, Turkmenistan, } \\
\text { Uzbekistan }\end{array}$ \\
\hline 18. EEA & European Economic Area & EC Iceland, Liechtenstein, Norway \\
\hline 19. EFTA & European Free Trade Association & Iceland, Liechtenstein, Norway, Switzerland \\
\hline 20. GCC & Gulf Cooperation Council & $\begin{array}{l}\text { Bahrain, Kuwait, Oman, Qatar, Saudi Arabia, United } \\
\text { Arab Emirates }\end{array}$ \\
\hline
\end{tabular}




\begin{tabular}{|c|c|c|}
\hline 21. GSTP & $\begin{array}{l}\text { General System of Trade Preferences } \\
\text { among Developing Countries }\end{array}$ & $\begin{array}{l}\text { Algeria, Argentina, Bangladesh, Benin, Bolivia, Brazil, } \\
\text { Cameroon, Chile, Colombia, Cuba, Democratic } \\
\text { People's Republic of Korea, Ecuador, Egypt, Ghana, } \\
\text { Guinea, Guyana, India, Indonesia, Islamic Republic of } \\
\text { Iran, Iraq, Libya, Malaysia, Mexico, Morocco, } \\
\text { Mozambique, Myanmar, Nicaragua, Nigeria, Pakistan, } \\
\text { Peru, Philippines, Republic of Korea, Romania, } \\
\text { Singapore, Sri Lanka, Sudan, Thailand, Trinidad and } \\
\text { Tobago, Tunisia, United Republic of Tanzania, } \\
\text { Venezuela, Vietnam, Yugoslavia, Zimbabwe }\end{array}$ \\
\hline 22. LAIA & $\begin{array}{l}\text { Latin American Integration } \\
\text { Association }\end{array}$ & $\begin{array}{l}\text { Argentina, Bolivia, Brazil, Chile, Colombia, Cuba, } \\
\text { Ecuador, Mexico, Paraguay, Peru, Uruguay, } \\
\text { Venezuela }\end{array}$ \\
\hline 23. MERCOSUR & Southern Common Market & Argentina, Brazil, Paraguay, Uruguay \\
\hline 24. MSG & Melanesian Spearhead Group & Fiji, Papua New Guinea, Solomon Islands, Vanuatu \\
\hline 25. NAFTA & $\begin{array}{l}\text { North American Free Trade } \\
\text { Agreement }\end{array}$ & Canada, Mexico, United States \\
\hline 26. OCT & Overseas Countries and Territories & $\begin{array}{l}\text { Greenland, New Caledonia, French Polynesia, French } \\
\text { Southern and Antarctic Territories, Wallis and Futuna } \\
\text { Islands, Mayotte Saint Pierre and Miquelon, Aruba, } \\
\text { Netherlands, Antilles, Anguilla, Cayman Islands, } \\
\text { Falkland Islands, South Georgia and South Sandwich } \\
\text { Islands, Montserrat, Pitcairn, Saint Helena, Ascension } \\
\text { Island, Tristan da Cunha, Turks and Caicos Islands, } \\
\text { British Antarctic Territory, British Indian Ocean } \\
\text { Territory, British Virgin Islands }\end{array}$ \\
\hline 27. PATCRA & $\begin{array}{l}\text { Agreement on Trade and Commercial } \\
\text { Relations between the Government of } \\
\text { Australia and the Government of } \\
\text { Papua New Guinea }\end{array}$ & Australia, Papua New Guinea \\
\hline 28. PTN & $\begin{array}{l}\text { Protocol relating to Trade } \\
\text { Negotiations among Developing } \\
\text { Countries }\end{array}$ & $\begin{array}{l}\text { Bangladesh, Brazil, Chile, Egypt, Israel, Mexico, } \\
\text { Pakistan, Paraguay, Peru, Philippines, Republic of } \\
\text { Korea, Romania, Tunisia, Turkey, Uruguay, Yugoslavia }\end{array}$ \\
\hline 29. SADC & $\begin{array}{l}\text { Southern African Development } \\
\text { Community }\end{array}$ & $\begin{array}{l}\text { Angola, Botswana, Lesotho, Malawi, Mauritius, } \\
\text { Mozambique, Namibia, South Africa, Swaziland, } \\
\text { Tanzania, Zambia, Zimbabwe }\end{array}$ \\
\hline 30. SAPTA & $\begin{array}{l}\text { South Asian Preferential Trade } \\
\text { Arrangement }\end{array}$ & $\begin{array}{l}\text { Bangladesh, Bhutan, India, Maldives, Nepal, Pakistan, } \\
\text { Sri Lanka }\end{array}$ \\
\hline 31. SPARTECA & $\begin{array}{l}\text { South Pacific Regional Trade and } \\
\text { Economic Cooperation Agreement }\end{array}$ & $\begin{array}{l}\text { Australia, New Zealand, Cook Islands, Fiji, Kiribati, } \\
\text { Marshall Islands, Micronesia, Nauru, Niue, Papua New } \\
\text { Guinea, Solomon Islands, Tonga, Tuvalu, Vanuatu, } \\
\text { Western Samoa }\end{array}$ \\
\hline 32. TRIPARTITE & Tripartite Agreement & Egypt, India, Yugoslavia \\
\hline 33. UEMOA WAEMU & $\begin{array}{l}\text { West African Economic and Monetary } \\
\text { Union }\end{array}$ & $\begin{array}{l}\text { Benin, Burkina Faso, Côte d'Ivoire, Guinea Bissau, } \\
\text { Mali, Niger, Senegal, Togo }\end{array}$ \\
\hline
\end{tabular}

Sources: WTO Website and websites of various RTCAs 
This paper presents the recent trends and patterns and nature of bilateral and RTCAs in Asia and associated problems and prospects. It also attempts to analyze and understand the latest wave of RTCAs and examines if they provide the basis for a new Asia-wide cooperation or for the emergence of new regional trade in blocs of several subregional groupings. Finally, it discusses the future shape of Asia's regional trade and cooperation agreements and the role of multilateral institutions in this regard.

\section{Nature and Forms of Regional Economic Cooperation}

The types or forms of regional cooperation can be classified into four broad categories: (i) regional and subregional economic cooperation programs (such as cross-border infrastructure, physical connectivity, and hardware and software, such as tariff harmonization); (ii) trade and investment cooperation and integration (such as FTAs, intraregional investment and WTO issues); (iii) monetary and financial cooperation and integration (such as regional policy dialogue, regional reserve pooling, financial market development, and exchange rates); and (iv) regional public goods (such as sustainable environment, clean energy and energy efficiency, environmental hazards, natural disaster responses, communicable diseases [HIVIAIDS/Avian Flu], governance, money laundering, terrorism, and human and drug trafficking).

The key factors behind the rapid emergence of RTCA in Asia include: (i) disillusionment and fatigue with unclear outcome of WTO agreements at Doha; (ii) inadequate experts capable of handling trade negotiations, particularly in less developed Asian countries; (iii) negative memories of the 1997 Asian crisis and its contagion effects; (iv) regionalism elsewhere, particularly in North America and Europe; (v) in-depth economic cooperation and integration easier in FTAs compared to the global free trade framework; (vi) complicated new political economic issues, diplomatic rivalry, etc.; (vii) the role of the United States as trend setter; (viii) aggressive pursuit of bilateral RTCAs by a few major Asian countries; (ix) human development and the increased recognition that poverty in developing countries could be effectively fought through increased trade and investments; and (x) short-term political trade-offs and gains to political leaders in power. Prior to the 1997 financial crisis, the private sector played the most important role in Asian trade integration. The emergence of India and the PRC as major economic forces in the world, with their greater openness to international trade also pushes close economic integration.

The nature of regional cooperation in Asia could be classified into five categories: (i) bilateral between two countries of the region, such as Singapore-India RTCA; (ii) subregional consisting of several countries in the region, such as, ASEAN Free Trade Agreement (AFTA); (iii) between one country and a subregion, such as, China-ASEAN RTCA; (iv) among three countries, such as, the India-Brazil-South Africa triangle considering a trilateral FTA and (iv) regional RTCAs including more than three countries in the region, such as proposed Asian Community.

\section{Regionalism and Multilateralism}

Economic cooperation and integration is based on complementarities that help maximize the mutual benefits of all involved. By working together, countries enjoy social and economic benefits that otherwise may not have occurred solely through individual efforts. Regional integration can produce win-win outcomes in both the quantity and quality of economic growth, while aiding in the reduction of global imbalances. More importantly, regional integration can also be a potential driver of sustainable economic growth that will contribute in poverty reduction 
goals in developing countries, if accompanied by pro-poor national policies.

While multilateralism is always favored among economists, there is a difference of opinion as to whether or not regionalism is a building block or a stumbling block for the global free trade framework. World-wide multilateral free trade is the eventual goal, but regionalism can be used as a stepping stone. The debate on the choice between regionalism or multilateralism, and the question on whether or not RTCAs are building or stumbling blocks for multilateralism is an ongoing issue that is yet to reach a conclusion. Some argue that the latest wave of RTCAs may produce a so-called "spaghetti bowl effect", and thus, will become stumbling-blocks for the global free trade framework. Bhagwati (1995) coined the term "spaghetti-bowl" proliferation of preferential trading arrangements.

The world economy has for three years been booming, so much so that even sub-Saharan Africa has registered GDP growth of almost $5 \%$ per year. So the question can be asked, when existing trading rules are producing such good results, does it matter whether or not we get some more liberalisation through the Doha Round?

In general, a subregional RTCA will contribute, through trade creation, to structural reforms in participating countries, which, in turn, will facilitate multilateral trading system. Countries with strong reservation against openness of domestic economy have to open their market to participating countries and, thus will be more open to multilateral trading framework.

According to the WTO Secretariat (1995), "RTCAs can strengthen multilateralism by moving generally at a faster pace than the multilateral system, and sharing its goals represent a way of strengthening the latter. There had been a definite trend toward broader and faster market access liberalization of non-tariff measures in RTCAs, in parallel to developments in the Multilateral Trading System (MTS). The positive effects of RTCAs on the integration of developing countries in the world economy are also noted. These views have been contested on the grounds of the fundamental changes observed in the geographical scale and tradepolicy scope of the RTCA process. It has been argued that the impact of these changes, coupled with the lack of flexible accession provisions in many RTCAs, hampers their effectiveness in contributing to the growth of world trade and the traditional synergies between the RTCA and multilateral processes".

Another important issue is the overlapping networks of RTCAs. Memberships to RTCAs overlap when individual countries participate in various distinct bilateral or subregional RTCAs. "The overlapping RTCA membership impacts on trade and investment patterns, increases the complexity of RTCAs, and magnifies negative effects on trade of complex and varying methods of determining regional content through preferential rules of origin. In addition, it has been argued that when diagonal cumulation is applied within an RTCA network (clusters of RTCAs, each with similar, if not identical, trade policy disciplines, developed in parallel), the preferential nature of any individual RTCA is extended to parties to other RTCAs, without any legal basis. Furthermore, such treatment is discriminatory, since some third parties to the original RTCA (those participating in the diagonal cumulation scheme) benefit from preferential treatment, while other third parties (those not participating in the scheme) are not eligible. Conversely, it has been argued that the constitution of RTCA networks acts as a positive force for the multilateral system. Parties to individual RTCAs within a network move toward the harmonization of rules of origin with the view to greater integration. Diagonal cumulation schemes under preferential rules of origin regimes reduce barriers and facilitate trade among

\footnotetext{
5 Inventory of Non-Tariff Provisions in Regional Trade Agreements, WT/REG/W/26, para. 32., WTO Website.
} 
participating economies by simplifying and harmonizing customs". ${ }^{6}$

\section{Trends in Subregional and Bilateral Trade and Cooperation Arrangements in Asia}

Asia is modernizing rapidly and has already become a powerhouse in the global economy. In this paper, a "subregion" is defined as a subgroup of Asian countries. Following the global trend, Asia has also witnessed a shift in regional trade strategy from multilateral to subregional and bilateral trade agreements. Bilateral trade accords are ascending, marking a shift from a regional emphasis on multilateralism. There are aggressive pursuits of these deals among Asian countries and between Asian and non-Asian countries. Subregional and bilateral regional cooperation and integration can help maximize the benefits of globalization, while minimizing its risks. On a broader scale, the impetus for further regional integration in Asia is a result of the relatively slow progress in multilateral trade talks at the global level, and the benefits of FTAs in Europe and the Americas.

In view of the rapid activities in other regions, the opportunity costs of not accelerating subregional and bilateral regional integration are higher for Asian countries. The most important question is if these bilateral and subregional RTCAs would provide building blocks for a new Asia-wide economic cooperation and integration or a new regional trade in blocks of several subregional groupings.

Prior to the discussion of the future trends in RTCA, one important issue that needs to be addressed is an understanding of what constitutes Asia. In other words, how do we define Asia for the purpose of trade integration? Here, Asia is defined to be a region in the world. Fortyseven Asian countries can be narrowly grouped into four subregions, namely, East and South East Asia, South Asia, Central Asia, and the Pacific. East and South East Asia consists of 15 countries- 10 ASEAN member countries (Brunei Darussalam, Cambodia, Indonesia, Lao People's Democratic Republic, Malaysia, Myanmar, Philippines, Singapore, Thailand and Viet Nam; and People's Republic of China, Japan, Korea, Hong Kong, China, Mongolia and Taipei, China. South Asia consists of 7 countries, namely, Afghanistan, Bangladesh, Bhutan, India, Maldives, Nepal, Pakistan, and Sri Lanka. Central Asia includes 6 republics, namely, Azerbaijan, Kazakhstan, Kyrgyz Republic, Tajikistan, Turkmenistan, and Uzbekistan. The Pacific consists of 16 countries, namely. Australia, Cook Islands, Fiji Islands, Kiribati, Marshall Islands, Fed. States of Micronesia, Nauru, New Zealand, Palau, Papua New Guinea, Samoa, Solomon Islands, Timor-Leste, Tonga, Tuvalu, Vanuatu. Only Mongolia is not a member of any Asian RTCAs. However, Asia's 47 countries are too broad for an Asia-wide RTCA.

The recent years have witnessed increased integration in Asia; however, in comparison to other regions, it is still one of the least integrated regions. Until recently, regional cooperation activities in Asia have focused mainly on subregional cooperation. In Asia, the major subregional economic cooperation initiatives include (i) Associations of South East Asian Nations (ASEAN) in East Asia, (ii) South Asian Association for Regional Co-Operation (SAARC) in South Asia, (iii) Greater Mekong Subregion Economic Cooperation Program (GMS) in Southeast and East Asia, (iv) South Asia Subregional Economic Cooperation (SASEC) in South Asia, (v) Bay of Bengal Initiative for Multi-Sectoral Technical and Economic Cooperation (BIMSTEC) in South and Southeast Asia, (vi) the Brunei Indonesia Malaysia the Philippines-East ASEAN Growth Area (BIMP-EAGA) in Southeast Asia, and (vii) Kunming Economic Cooperation Initiative among Bangladesh, the People Republic of China (PRC), India and Myanmar in South and East

6 Compendium of issues related to regional trade agreements, TN/RL/W/8/Rev.1, p 27-28,1 August 2002, http://docsonline.wto.org/DDFDocuments/t/tn/rl/W8R1.doc, WTO website.. 
Asia. GMS, BIMP-EGA, and SASEC are more related to cooperation regarding cross-border infrastructure development and regional public goods.

A new dimension of regional cooperation is evolving as "bridges" and "linkages" are being built across subregions. There are several FTAs between various subregions of Asia, with ASEAN and India Free Trade Agreements, Singapore-India FTA and Thailand-India FTA as prominent examples. In addition, the Asia Cooperation Dialogue among countries in South Asia, East Asia, and several Middle Eastern Countries had addressed the area of money and finance, and the possibility of joint infrastructure projects between SASEC and GMS. Kawai (2005), Naya and ADB (2005) presented RTCAs' surveys in Asia.

Bilateral regional cooperation and integration can help maximize the benefits of globalization, while minimizing its risks. But on a broader scale, the impetus for more regional integration in Asia has resulted from the benefits of FTAs in Europe and the America and the relatively slow progress in multilateral trade talks at the global level. Furthermore, there has been a shift in regional trade strategy, and bilateral trade accords are ascending, marking a shift from a regional emphasis on multilateralism. With the aggressive pursuit of these bilateral trade deals among Asian countries and between Asian and non-Asian countries, the opportunity costs of not accelerating bilateral regional integration are high for Asian countries (Bhattacharyay and De, 2005). In recent years, bilateral agreements have mushroomed in Asia. There are around 175 bilateral and regional trade agreements in existence or under negotiation compared to just a handful a decade ago $^{7}$. While multilateralism is always favored among economists, there is a difference of opinion as to whether or not regionalism in the form of bilateral or subregional cooperation is a building block or a stumbling block for the global free trade framework.

"Bilateral and subregional RTCAs are often one component of a larger political effort to deepen economic relations with neighboring countries [(Devlin and Estevadeordal (2004) and Schiff and Winters (2003)] In general, these agreements can create opportunities to expand trade through joint action to overcome institutional as well as policy barriers to trade. At a basic level, it is usually easier to motivate reciprocal reductions in border barriers when the participants are fewer and the policymakers feel more in control of outcomes. Furthermore, RTCAs have the flexibility to pursue trade-expanding policies not addressed well in multilateral trading rules. Therefore, trade agreements usually go beyond reducing trade tariffs to include measures to reduce trade impediments associated with standards, customs and border crossings, and services regulations-as well as broader rules that improve the overall investment climate. In addition, these RTCAs often form cornerstones of larger economic and political efforts to increase regional cooperation. Therefore, RCTAs can help motivate and reinforce broader reforms in domestic policy; they can be designed to contribute to a political environment that is more conducive to stability, investment, and growth" (World Bank, 2004).

Tables 3 and 4 in the appendix present major subregional and bilateral Free Trade Agreements in Asia under negotiation or implementation. These tables also explain the type and nature of RTCAs, status of negotiation, and implementation.

\section{New Trade Blocks in Asia: Problems and Prospects}

With the ongoing economic reform program and market liberalization process gradually extending to Asian economies, new prospects for economic opportunities have emerged. An ambitious and bold Asia-wide trade liberalization process is ongoing. However, actual

\footnotetext{
${ }^{7}$ Estimated from Asian Development Bank's FTA Database: http://aric.adb.org/regionalcooperation/index.asp.
} 
realization for a pan-Asian RTCA is still a distant vision, and it is difficult to predict a timeframe for the realization of this goal. The process of Asian trade and economic integration will be multilayered. The present reality is a proliferation of bilateral and subregional RTCAs. Even though this shows a drift away from WTO multilateralism, a wave of interlocking bilateral and multilateral RTCAs across Asia could be the appropriate way of attaining an Asia-wide integration in the long-term, particularly in light of an imperfect global environment.

Asia's vast cultural, social, and economic diversity makes regional integration a difficult and complex task, requiring careful prioritization of achievable targets. In view of the large number (47) and heterogeneous nature of Asian countries, it is difficult to foresee a pan-Asian RTCA including all Asian countries. The important questions which require immediate attention are: What is the definition of a Pan-Asia RTCA? Do we continue the subregional approach or go to Pan-Asian regional cooperation immediately? What countries should comprise the initial group that can be considered for integration if a phased approach is taken?

In view of the significant cultural, economic, and social disparities in Asia among the subregions and among countries, a multi-speed, multi-phased and multi-track approach should be encouraged for constructing an Asia-wide RTCA. One feasible area where most Asian countries could join is that of public goods to have Asia-wide cooperation in this area. However, many countries are not ready to join such a regional trading arrangement within the next five or ten years.

The subregionalism process in Asia, such as ASEAN, SAARC, and BIMSTEC, has so far been mostly outward-oriented, flexible, and supportive of the multilateral process of liberalization. The future direction of the open regionalism in Asia is, however, not very clear. The recent wave of bilateral agreements may become stumbling blocs to multilateralism and regionalism and may fragment the region unless they are compatible with each other and with the WTO agreements. The East Asian region is witnessing expansion of subregional groups into larger free trade areas, such as the expansion of ASEAN to ASEAN Plus Three (China, Japan, and Korea) and East Asia Summit. On the other hand, the South Asian Region is facing the emergence of new cooperation where some countries of the larger group have been excluded and new countries of other region have been included, notably the emergence of BIMSTEC.

In recent years bilateral agreements have mushroomed in Asia. During the last 15 years, the number of bilateral investment treaties (BITs) increased to about 2,300 in 2003 from 400 in the early 1990s. These BITs assure the protection of property rights of foreign investors, thus, giving foreign investors confidence that counties are open with predictable investment regime. At the same time, these treaties are used to enforce property rights infractions (Sauve, 2004).

Scollay (2003) argued that bilateral agreements may undermine subregional/regional RTCAs by allowing the emergence of a "hub and spoke" configuration. It appears that major high-income countries and trading powers in Asia are involved in an aggressive race through bilateral RTCAs in an attempt to secure trade hegemony in the region. In addition, middle income countries and smaller trading powers are also highly involved in securing bilateral RTCAs, and may also be competing to act as hubs. This could be a defensive trade strategy to combat the threat of ending up at the spoke end of a major hub. A multilayered structure is evolving consisting of a dominant hub-and-spoke arrangement with sublayers of other hub-and-spoke arrangements in which smaller economies and trading powers are attempting to combat more aggressive strategies by collectively establishing alternative hubs.

The PRC and Japan, being the largest economies in Asia, can act as major hubs. At the same 
time, India can also play a role of major hub due to its relative geographical and economic size and connectivity in South Asia. The ASEAN could act as a major hub, and thus assist in building confidence in spoke countries. Likewise, SAARC, and BIMSTEC can play a role of hub in negotiating RTCA with ASEAN. There could be FTA between two subregional groups like ASEAN and SAARC.

A 'hub-and-spoke' shape is emerging in the RTCAs in Asia. "Hub" countries are negotiating bilateral treaties with many different types of spoke countries. Hubs will be able to negotiate favorable agreements due to their disproportionate power in negotiations. Furthermore, reductions in tariffs in spoke countries do not allow them access to each other's markets.

A subregional RTCA observes the principle of non-discrimination among members. Therefore, all member countries will receive the same treatment. On the other hand, in a hub-and-spoke arrangement, each spoke country will negotiate a separate agreement with the hub country. The agreement will be made to suit the common interests of the hub and its respective spoke countries. It is important to ensure that bilateral agreement are not based on exclusivity and do not depart from the inclusiveness embodied in the most favored nation (MFN) principle. Moreover, such agreements should not be discriminatory (i.e. not built on power relations) but should instead be based on a multilaterally agreed body of norms, rules, and principles that apply equally to all. Each spoke country's comparative advantage is in a particular set of sectors, and therefore, trade liberalizations will focus on the specific needs of that country and other sectors will be excluded from liberalization. In addition, a hub country will be inclined to include various safeguard clauses and relatively stringent rules of origin to protect their import competing industries. The nature of agreements will be determined by vested interests and future liberalizations may be difficult to implement. On the other hand, the opportunity for exceptions is much less in a subregional RTCA as members will deliberate different preferences regarding the extent of exclusion of sectors from liberalization and ultimately will have to finalize a commonly agreed set of sectors. Many industrialized economies have established or negotiated bilateral RTCAs frequently based on power relations (Kosteci and Hoekman, 2001 and Bonapace, 2005).

The major problems with hub-and-spoke arrangement include the lack of adequate market access among spoke countries, while hub countries have much larger negotiating power. However, because of an imperfect global situation with several economically heterogeneous countries, bilateral agreements could be an essential step towards a long-term emergence of an Asian market.

If bilateral and subregional RTCAs are compatible with each other and with WTO agreements, then they will be building blocks for worldwide multilateral agreements. Asian countries recognize that bilateral and subregional trade agreements can contribute towards accelerating regional and global liberalization and can act as building blocks within the framework of multilateral trading system and towards the formulation of Asian community.

In general, a subregional RTCA will contribute, through trade creation, to structural reforms in participating countries, which, in turn, will facilitate multilateral trading system. Countries with strong reservation against openness of domestic economy have to open their market to participating countries and, making them more open to multilateral trading framework.

Ornelas (2005) argued that RTCA's achieve more-or-less the same outcome as multilateral trading arrangements. He showed that "under an FTA, far from increasing the lobbying against the countries that are not members of the FTA, the reverse happens, because if a country has 
higher tariffs for imports from outside countries, the surplus has to be shared with everyone within the FTA. It doesn't stay within the domestic boundaries. Therefore, "the domestic producers become less willing to compensate the government for higher external tariffs on excluded countries." From this, he concluded that "RTCAs achieve more-or-less the same outcome as multilateral trading arrangements".

\section{Future Shape of RTCAs in Asia}

The dream of an Asia-wide free trade and investment cooperation encompassing 47 countries is not feasible in the medium term. In view of an imperfect Asian region with significant economic and social disparities, a phased and multi-track approach towards a pan-Asian RTCA is an appropriate process. Regarding the latest wave of existing bilateral RTCAs, the major challenge is how they can be made compatible, consolidated, and united.

At present, there are three major active trade blocs consisting of Asian countries only, namely the ASEAN Free Trade Agreement (AFTA initiated in 1992, South Asian Preferential Trade Agreement (SAPTA signed in 1992, and BIMSTEC agreement involving five South Asia and two South East Asian countries adopted in 2004. In addition, there are three other major trade blocs involving both Asian and non-Asia countries: (i) Pacific Agreement on Closer Economic Relations (PACER) includes Australia, New Zealand and other pacific countries; (ii) the Asia Pacific Economic Cooperation ${ }^{8}$ (APEC established in 1989 and a major economic cooperation involving 15 Asian countries and 6 non-Asian countries ( the scope of APEC does not include tariff preferences to member countries, however, it is seeking a free and open trade and investment for industrialized economies by 2010 and developing economies by 2020); (iii) Economic Cooperation Organizations (ECO) consisting of 6 central Asian republics (Azerbaijan, Kazakhstan, Kyrgyz Republic, Tajikistan, Turkmenistan, and Uzbekistan) and Afghanistan, Iran, Pakistan, and Turkey (it is progressing toward its objectives through three major pillars: trade liberalization, trade facilitation and other trade related facilities and has a preferential trade arrangements among its members).

The future shape of trade blocs in Asia will be based on consolidation and expansion of subregional groupings into a more cohesive arrangement, along with the establishment of common principles for a regional economic partnership to include broader areas of economic cooperation. Table 2 presents the future shape of Asia's regional trade and cooperation agreements. The first large trade bloc will consist of ASEAN countries. Other major Asian countries will join the group in four stages reaching a very large trade bloc consisting of 19 Asian counties. The remaining countries will join at various stages once they are ready.

\section{Stage 1}

The starting point of a trade bloc in Asia is the successful implementation of ASEAN Free Trade Area (AFTA), the first comprehensive RTCA in Asia that is already implementing its vision of building an ASEAN Economic Community by 2020. The AFTA was the only regional preferential trade/tariff agreement in East Asia until November 2001. The major problem is that the ASEAN economy is not large enough like the EU and NAFTA as Asian countries do not have adequate complimentarity. ASEAN has been successful in reducing tariffs under AFTA for

8 Members countries are: Australia, Brunei Darussalam, Canada, Chile, People's Republic of China, Hong Kong, China, Indonesia, Japan, Republic of Korea, Malaysia, Mexico, New Zealand, Papua New Guinea, Peru, Philippines, Russia, Singapore, Chinese Taipei, Thailand, United States, and Viet Nam 
its member countries in many manufacturing products.

Table 2: Future Shape of Asia's Regional Trade and Cooperation Agreements

\begin{tabular}{|c|c|c|c|}
\hline Stage & $\begin{array}{l}\text { No. of Countries in the } \\
\text { Group }\end{array}$ & $\begin{array}{l}\text { Member Countries in } \\
\text { the Group }\end{array}$ & Time Horizon \\
\hline Stage 1 & 10 & ASEAN countries $^{9}$ & Near Future \\
\hline Stage 2 & 13 & $\begin{array}{l}\text { ASEAN countries, } \\
\text { Japan, China, and } \\
\text { Korea }\end{array}$ & Short-term \\
\hline Stage 3 & 14 & $\begin{array}{l}\text { ASEAN countries, } \\
\text { Japan, China, Korea } \\
\text { and India }\end{array}$ & Medium-term \\
\hline Stage 4 & 19 & $\begin{array}{c}\text { ASEAN countries, } \\
\text { Japan, China, Korea, } \\
\text { India, New Zealand, } \\
\text { Australia, Pakistan, } \\
\text { Bangladesh and Sri } \\
\text { Lanka }\end{array}$ & Long-term \\
\hline
\end{tabular}

Agreement on a Common Effective Preferential Tariff Scheme for ASEAN was signed in January 1992 and became effective in January 1993. It aims to integrate ASEAN economies into a single productive region, capitalizing on a regional market of 500 million people. The member countries signed the Protocol to amend the Common Effective Preferential Tariff (CEPT)-AFTA Agreement on 30 January 2003, while committing to eliminate tariffs on the products in their inclusion list. They have made significant progress in lowering intraregional tariffs through CEPT Scheme for AFTA. More than 99\% of the products in the CEPT Inclusion List (IL) of ASEAN-6, comprising Brunei Darussalam, Indonesia, Malaysia, the Philippines, Singapore and Thailand, have been brought down to the $0-5 \%$ tariff range. This is much beyond the $60 \%$ target. ASEAN's newer members, namely Cambodia, Laos, Myanmar, and Viet Nam have moved almost $80 \%$ of their products into their respective CEPT IL. Of these items, about $66 \%$ already have tariffs within the $0-5 \%$ tariff band. Viet Nam has until 2006 to bring down tariff of products in the IL to no more than 5\% duties, Laos and Myanmar in 2008, and Cambodia in 2010.

\section{Stage 2}

East Asia which can be defined as ASEAN Plus Three, namely ASEAN countries, China, Japan, and Korea, is the most integrated subregion in Asia. The intra-regional trade of this subregion accounts more than half og Asia's total trade. The next emerging trade block will be ASEAN, +3 comprising of 10 ASEAN nations, China, Japan and South Korea. They, meet annually under a loose framework called the ASEAN Plus Three Meeting on Regional Cooperation. Japan has

\footnotetext{
${ }^{9}$ Brunei Darussalam, Cambodia, Indonesia, Laos, Malaysia, Myanmar, Philippines, Singapore, Thailand, Vietnam
} 
already signed RTCAs with Singapore in 2000 (under implementation), Mexico in 2004, and Malaysia in 2005. It is aggressively pursuing bilateral RTCAs with China, Indonesia, India, the Philippines, South Korea, and Thailand. The agreements with Philippines and Thailand are expected to be completed by end of 2006. Japan has also recently drawn up plans to conclude 15 such agreements, including with the ASEAN by 2010. On 27 March 2006, Japan established the Japan-ASEAN Integration Fund (JAIF) to support ASEAN's integration efforts towards the realization of the ASEAN Community, as envisaged in the Declaration of ASEAN Concord II of 2003 (commonly referred to as the Bali Concord II). The funds will be utilized to implement activities of the Vientianne Action Programme (VAP) and promote greater cooperation between ASEAN and Japan. This shows a clear departure from aggressive bilateral agreements pursued by Japan towards a subregional agreement that further strengths the ASEAN+3 process.

Following accession to the WTO in 2002, PRC is pursuing regional trade agreements at a rapid pace. China has decided to focus on bilateral FTAs and planned to negotiate FTAs with 27 countries during 2006. ${ }^{10}$ The mainland looks forward this year. It has already concluded agreements with Hong Kong, China, and Macao (a Closer Economic Partnership Arrangement), China; ASEAN, Australia and New Zealand. It is also either in negotiation or under discussion with Chile, India, the Gulf Cooperation Council, Japan, Korea, Pakistan, and South Africa. In 2005, China signed an FTA cargo trade agreement with Chile and an agreement on an "early harvest" program with Pakistan. These agreements differ sharply in form and substance, and involve process commitments to ongoing negotiation and cooperation on a wide range of issues (Antkiewicz and Whalley, 2005). PRC also gained observer status in the SAARC at the 13th summit of the regional organization held in Dhaka, Bangladesh, in November 2005.

\section{Stage 3}

Under the banner of the Asian Summit, Australia, India, and New Zealand will join the ASEAN Plus Three group. These countries have signed or negotiated bilateral agreements with many ASEAN Plus Three countries (see Table 2). The first East Asian summit of regional leaders of the above countries was held in Kuala Lumpur on 14 December 2005. It will have a significant future impact in the formation of larger trade block. On the occasion of the historic First East Asia Summit, the Heads of State/Government of the Member Countries of ASEAN, Australia, and People's Republic of China, Republic of India, Japan, Republic of Korea, and New Zealand signed the Kuala Lumpur Declaration. The declaration highlights the importance of strengthening bilateral and multilateral interaction and cooperation among participating countries of the East Asia Summit and the world on issues of common interest in order to enhance peace and economic prosperity.

The declaration aims to: (i) Foster strategic dialogue and promote cooperation in political and security issues to ensure that our countries can live at peace with one another and with the world in a just, democratic and harmonious environment; (ii) promote development, financial stability, energy security, economic integration and growth, eradicate poverty and narrow the development gap in East Asia, through technology transfer and infrastructure development, capacity building, good governance and humanitarian assistance, promoting financial links, trade and investment expansion and liberalization; and (iii) promote deeper cultural understanding, people-to-people contact and enhanced cooperation in uplifting the lives and well-being of our people in order to foster mutual trust and solidarity as well as promoting fields such as environmental protection, prevention of infectious diseases and natural disaster

10 http://www.bilaterals.org/article.php3?id_article=3405 
mitigation. $^{11}$

It is expected that a more formal East Asian Summit would supersede the ASEAN Plus Three framework and underscore the region's seriousness in pursuing goals to achieve a European Union-style single market and community by 2020 .

India has been very active in negotiating bilateral trade agreements, primarily with other developing countries. It belongs to SAARC and BIMSTEC, Kunming cooperation. It has concluded limited free trade agreements with Sri Lanka (1998) and Thailand (2003). In addition, it signed a number of preferential trade/tariff agreements (tariff concession schemes) with countries/blocs such as Afghanistan and Mercosur. In June 2005, it concluded a Comprehensive Economic Cooperation Agreement (CECA) with Singapore, which is India's first "comprehensive" FTA. The 1998 India and Sri Lanka FTA will be upgraded into a Comprehensive Economic Partnership Agreement in early 2006. India signed and PTA with Chili in March 2006. At present, it is undertaking bilateral negotiations with ASEAN, Bangladesh (revised and stronger trade agreement) and Korea, about to start with Mauritius and the GCC. At the same time, India is proposing negotiations with Egypt and SACU (Southern African Customs Union). It also belongs to the India-Brazil-South Africa triangle (IBSA) which is considering a trilateral FTA. It is planning for FTA with several Asian nations, including Indonesia, Japan, Korea, Malaysia, and PRC. ${ }^{12}$

A study by Bhattacharya and Bhattacharyay (2006) using a gravity model indicates that due to Japan and BIMSTEC countries RTCA, Japan's increase in import from BIMSTEC countries will be marginal; however, its exports to BIMSTEC countries will increase significantly. This is due to the tariff levels existing between Japan and BIMSTEC. The study's conclusion supports the idea that it will be beneficial for industrialized Asian countries like Japan, Korea and Singapore to have an agreement with subregional groupings, such as ASEAN, BIMSTEC as a whole, rather than bilateral agreements with each individual country. In addition, cost and resources required for individual bilateral agreements could be much higher than those for subregional agreements. Inclusion of additional countries of ASEAN will pave the way for Asia-wide integration.

Japan is proposing a US\$80 million to US $\$ 100$ million fund over a 10 -year period to establish a Comprehensive Economic Partnership in East Asia (CEPEA) spanning 16 countries under the Nikai Initiative which will foster closer economic linkages among the 10-member ASEAN, and China, Japan and South Korea, plus India, Australia and New Zealand. Japan's Ministry of Economy Trade and Industry formulated the Nikai Initiative, following the 11th ASEAN Summit in Kuala Lumpur last December (South Information Gateway, 2006) ${ }^{13}$. It is expected that a more formal East Asian Summit would supersede the ASEAN Plus Three framework and underscore the region's seriousness in pursuing goals to achieve a European Union-style single Asian market and community by 2020. The proposed free trade area of Asian Community would create a combined population (or a consumer base) of 3.1 billion people and combined gross domestic product of almost $\$ 10$ trillion, or almost half of the world's population and a quarter of its GDP.

\section{Stage 4}

In view of the high growth rates and large market sizes of some South Asian countries,

\footnotetext{
11 ASEAN Secretariat Website, 2005-http://www.aseansec.org/18098.htm).

12 http://www.bilaterals.org/rubrique.php3?id_rubrique=88.

$13 \mathrm{http}: / /$ webevents.bernama.com/ssig/index.php?option=com_content\&task=view\&id=3085
} 
countries such as Bangladesh, Pakistan, and Sri Lanka will be invited to join the trading block. Pakistan signed the Instrument of Accession to the Treaty of Amity and Cooperation in Southeast Asia, Jakarta, on 2 July 2004. Pakistan is negotiating RTCAs with Singapore, Malaysia and China. The next entry to the trade block will be Pakistan. Sri Lanka has already signed RTCAs and proposed one with Singapore. Subsequently, remaining Asian countries will join in stages when they are ready. This will lead to a giant free trade area modeled on the North American Free Trade Area without a monetary union in the form of a single currency.

There are various forms of economic cooperation, such as regional public goods, trade and investment, monetary and financial cooperation, and cross-border infrastructure. Ideally, various forms of cooperation should be implemented in phases as they require different policy measures and institutional mechanisms as prerequisites. However, some form of cooperation could be undertaken simultaneously.

Today's trade issues go beyond the traditional mechanisms of tariffs and quotas and include "behind-the-border" issues, such as the role of infrastructure and governance in supporting a well-functioning trading economy. International transport services liberalization fosters international trade in much the same way tariff liberalization does. Developing countries will have to quickly acquire the needed expertise on a whole lot of complex issues of trade facilitation, so that they can negotiate more effectively and ensure that agreements serve their objective of poverty reduction. The adequacy in trade facilitation measures (both visible and invisible) helps determine one region's success and another's failure. For instance, it is the transport infrastructure and user-friendly transaction instruments that have helped European countries in uniting together, whereas the lack of integrated transport network has prevented South Asia from reaching a similar level of integration. Therefore, working together for trade facilitation, an essential element to promote international trade, will pave the way for a "win-win" situation in the globalization programmes. However, it is important to note that trade liberalization under RTCAs is necessary but not a sufficient condition. To achieve any substantial progress in bilateral and regional trade among the asian countries, utmost priority should be given for the development of infrastructural facilities. Added to this, complimentary policy reform, accompanied by improved procedural and operational efficiency, in the transport sector is essential to support trade liberalization in Asia (De and Bhattacharyay, 2006).

Several Asian countries have successfully built cross-border infrastructure. Countries under the Mekong region ${ }^{14}$ have been quite successful in building cross-border infrastructure, such as transport, and telecommunications. This process should be further enhanced in Asian countries, particularly those connected geographically. The scope should cover cross-sector and multilayered inter-linkages spanning trade, investments, and financial markets. At the same time, the associated software, such as laws, rules and regulations should be harmonized.

In view of the recent catastrophes, such as the Asian Tsunami, the South Asian earthquake, and trans-boundary threats Avian flu, SARS, HIVIAIDS, environmental hazards and crossborder terrorism, a pan-Asian regional cooperation should be established to combat the spread of communicable diseases, natural disasters, terrorism, money laundering, drug and women trafficking and environmental degradation. The cooperation could set-up a liquidity support initiative for member countries in case of distress arising out of security problems and natural disasters.

14 Countries that are part of the Mekong Region include Thailand, Myanmar, Lao People's Democratic Republic Cambodia, Vietnam and Yunnan Province in China. 
Some forms of financial cooperation can be pursued simultaneously with the trade and investment cooperation in stages. These stages are (i) cooperation information sharing and peer pressure to strengthen domestic and regional financial system, (ii) developing effective mechanisms for regulation and supervision of financial sectors; and (iii) harmonization of rules, regulations and prudential norms of financial systems. The above financial cooperation will assist in preventing and combating future financial crises. ASEAN Plus Three countries are already implementing an economic and financial surveillance process.

\section{Roles of Multilateral Institutions}

Trade and investment cooperation and integration are being enhanced more on private sector initiatives than government interventions in Asian countries. At the first stage, further enhancement of trade and investment integration should be undertaken through forging a larger trading bloc as envisaged in the earlier section. It is important to ensure that all RTCAs are compatible with the WTO, with each other, and with subregional RTCAs so that these can be used as stepping stones for Asia-wide RTCA. Multilateral and regional organizations such as World Bank, International Monetary Fund (IMF), the Asian Development Bank (ADB) and UNESCAP can help ensure that RTCAs will complement the activities of the WTO by carrying out a "mapping service" that would assist countries in taking stocks and reviewing RTCAs.

Multilateral institutions such as the IMF, World Bank, and ADB can help the integration process (within their mandates) by helping test ideas, working toward improved effectiveness, avoiding duplication, and taking on a subsidiary role in supporting and nudging forward the regional policy agenda. They can also act as a conduit for understanding, both bringing global insights to the region and bringing an understanding of the region to regions such as the US and the EU.

ADB has supported regional economic cooperation activities in its Asian member countries. In 1994, ADB approved a policy that formalized its role as a catalyst for regional cooperation. More recently, ADB's Poverty Reduction Strategy and Long Term Strategic Framework for 20012015 formally identifies regional cooperation as a core component of ADB's overarching goal of reducing poverty.

ADB supports regional cooperation by playing a catalytic role in facilitating the exchange of information between developing member countries, and the mobilization of resources to finance regional projects. Under the regional cooperation program, ADB has been supporting ASEAN and ASEAN plus People's Republic of China (PRC), Japan, and Republic of Korea (ASEAN+3), Greater Mekong Subregion Program (GMS), the Brunei-Darussalam-IndonesiaMalaysia-Philippines-East ASEAN Growth Area Initiative, the Central Asia Regional Economic Cooperation Program (CAREC), and the South Asia Subregional Economic Cooperation Initiative (SASEC). These initiatives have contributed significantly in enhancing connectivity, reducing barriers to intraregional trade and investment, addressing cross-border issues, such as sectoral, environmental, and social safeguards, exchange of information and experience, undertaking joint research/study, promoting policy dialogue, strengthening institutions, economic surveillance, currency swap arrangements, and regional bond market initiatives. In April 2005, ADB established the Office of Regional Economic Integration to provide strategic focus in Asian regional cooperation and integration. $A D B$ is now preparing a "Regional Cooperation and Integration Strategy" through implementation of which it will act as an effective regional focal institution in supporting and promoting Asian regional cooperation and integration process. 


\section{Conclusion}

The environment for greater integration in Asia is better than ever while the opportunity cost of non-integration continues to increase. As a result of market-oriented reforms in past decade or so in South Asian countries, economic growth has accelerated more evenly across subregions in Asia than in the past, which predicts well the intraregional or Asia-wide cooperation and integration. Substantial progress has been achieved in regional cooperation among ASEAN Plus countries. Similar efforts have been initiated among SAARC countries recently.

Reconstruction in Afghanistan provides an opportunity for greater economic ties among Central Asian Republics, South and East Asia.

With the unsuccessful WTO trade talks in 2003 at Cancun, there is an increasing trend toward regional integration, particularly toward bilateral and regional preferential trade/tariff agreements in Asia and in other regions. With the aggressive pursuit of these bilateral trade deals among Asian countries and between Asian and non-Asian countries, the opportunity costs of not accelerating bilateral regional integration are high for Asian economies.

Asia's vast cultural, social, and economic diversity makes regional integration a difficult and complex task, requiring careful prioritization of achievable targets. However, with increasing integration in other regions, particularly the expanded $\mathrm{EU}$, the opportunity costs of not moving toward greater integration in Asia could be increasing. While economic integration can produce significant economic and social benefits, it may also lead to sectoral and distributional imbalances, creating political, economic, social, and environmental challenges. Therefore, there is a need to discuss Asia's growing economic integration in terms of developing the most effective means of harnessing its potential.

The dream of an Asia-wide RCTA encompassing 44 countries is not expected to be fulfilled in the medium term. In the imperfect Asian region, a phased approach toward a pan-Asian RCTA is the right process. Regarding the latest wave of bilateral RTCAs, the important issue is how they could be consolidated, combined, and unified. Under the banner of the Asian Summit, a trade block consisting of ASEAN member countries, and major Asian countries, such as, Australia, India Japan, Korea, PRC, and New Zealand should be the first major trade block toward the longer-term construction of an integrated Asian market. Subsequently, other major south Asian countries, such as Pakistan, Sri Lanka and Bangladesh can join. In due course, the remaining Asian countries can join once they are ready.

If bilateral and subregional RTCAs are compatible with each other and with the WTO agreements, then they will be building blocks for world-wide multilateral agreements. Asian countries recognize that bilateral and subregional trade agreements can contribute towards accelerating regional and global liberalization and can act as building blocks within the framework of multilateral trading system. For a successful pan-Asia integration, countries should focus on economic issues instead of political and security matters.

Multilateral institutions can help the integration process along (within their mandates) by helping test ideas, working toward improved effectiveness, avoiding duplication, and taking on a subsidiary role in supporting and approaching the regional policy agenda. They can also act as a conduit for understanding, both bringing global insights to the region and bringing an understanding of the region to regions. 
In terms of archiving various forms and areas of economic cooperation and integration, the most pressing question is how to sequence them. Most feasible sequencing would be trade, finance RTCA, and the weaker forms of monetary cooperation first before considering full monetary union. Another area which needs attention is how to ensure that the outcome of integration is pro-poor and equitable, both within and among countries, and open to the rest of the world.

Asian countries need to establish an Asian community secretariat, which will purse the initiatives to widen cooperative arrangements and to study the possibility of pursuing deeper economic cooperation and integration. Governments and key institutions should understand the challenges and complexities associated with deepening Asian economic cooperation and integration. Moving the vision closer to reality requires defining a clear direction for Asian economic cooperation and integration, and identifying strategies and actions to get there.

Finally, an advocacy of enhanced cooperation among major Asian economies does not imply any restriction upon multilateral WTO global trade framework or other existing regional cooperation in Asia and the rest of the world. Cooperation among major Asian countries (in matters of trade and/or investment) is sustainable regardless of operation of other multicountry cooperation initiatives. Other larger cooperation initiatives containing Asian and non-Asian countries should not be perceived as constraints in developing potential cooperation among Asian economies. Efforts should be made to develop proper and compatible Asian regional cooperation which, in turn, will enhance WTO multilateral cooperation.

\section{References}

Antkiewicz, Agata; Whalley, John, China's New Regional Trade Agreements, The World Economy, Volume 28, Number 10, October 2005, pp. 1539-1557(19), Blackwell Publishing, London, October 2005.

Asian Development Outlook, Asian Development Outlook 2006, Asian Development Outlook, Manila, 2006.

Asian Development Bank, "Asian Economic Cooperation and Integration" Progress, Prospects and Challenges", Asian Development Bank, Manila 2005.

Bhagwati, J. (1995). "U.S. Trade Policy: The Infatuation with Free Trade Areas", in The Dangerous Drift to Preferential Trade/Tariff Agreements, Washington, DC: The AEI Press.

Bhagwati, J. (1997). "The Global Age: From a Skeptical South to a Fearful North", The World Economy, 20, pp.259-83.

Bhattacharyay, Biswa N., and P. De. "Promotion of Trade and Investments between People Republic of China and India: Toward a Regional Perspective", Asia Development Review, Vol. 22, no. 1, pp.45-70, 2005.

Bhattacharya Swapan K. and Bhattacharyay, Biswa N., "Prospects and Challenges of Regional Trade, and Investment in Asia: An Empirical Analysis on BIMSTEC Countries and Japan", CESIfo Working Paper, No. 1725, Center for Economic Studies and Ifo Institute for Economic Research, University of Munich, Munich, Germany, May 2006.

Bonapce, T., Free Trade Areas in the ESCAP Region: Progress. Challenges, and Prospects, 
Chapter 5, "Asian Economic Cooperation and Integration" Progress, Prospects and Challenges", Asian Development Bank, Manila 2005.

De P., and Bhattcharyay, Biswa N.., "Strengthening Regional Economic Cooperation through Bilateral Cooperation: Status and Prospects of India-Bangladesh Cooperation in Context of South Asian Regional Cooperation", forthcoming working paper, Asian Development Bank, Manila, 2006.

International Monetary Fund, World Economic Outlook: Globalization and Inflation, IMF, Washington D.C., April 2006.

Kawai, Masahiro, "East Asian Economic Regionalism: Progress and Challenges", Journal of Asian Economics, Vol. 1691), spring 2005.

Kosteci and Hoekman, The Political Economy of the Multilateral Trading System, Oxford, Oxford University Press, 2001.

Maddison, Angus (2001) The World Economy- A Millennial Perspective. OECD.

Naya, Seiji F., "The Asian Development Experience”, Asian Development Bank, Manila, 2002.

Ornelas, Emanuel, "Rent destruction and the political viability of Free Trade Agreements", The Quarterly Journal of Economics, 2005, Vol. 120, MIT Press, Cambridge.

Oxford Analytica, EAST ASIA: Trade deals challenge multilateralism, 22 June 2005.

Radelet, Steven, Sachs, Jeffrey and Jong -Wha Lee (November 1997). "Economic Growth in Asia". Development Discussion Paper No. 609. Harvard Institute for Development.

Scollay, Robert, "Economic Impact of RTAs in Asia and the Pacific", paper presented at the Expert Group Meeting on Regional Trade Agreements in Asia and the Pacific, Bangkok, 30-31 January 2003.

Sauve, Pierre, "Promise and Pitfalls of the WTO and FTAs: Investment and Trade in Services", Speech on the Brown Bag Lunch Seminar, Research Institute of Economy, Trade and Industry, http://www.rieti.go.jp/en/events/bbl/04110101.html, Tokyo, November 2004

Wilson and Purushotaman. "Dreaming with BRICs: The Path to 2050". Global Economic Paper: 99. Goldman and Sachs, New York, 2003.

Venables, A. J., "Winners and Losers from Regional Integration Agreements." The Economic Journal 113(October):747-61, 2003.

WTO, Regionalism and the World Trading System, WTO Secretariat, 1995. 


\section{Appendix}

\section{Table 3: Major Bilateral Free Trade Agreements in Asia ${ }^{15}$ under Negotiation/Implementation}

\begin{tabular}{|c|c|c|}
\hline Initiatives & Status & Description \\
\hline $\begin{array}{l}\text { Canada- Singapore } \\
\text { Free Trade } \\
\text { Agreement } \\
\text { (CSFTA) }\end{array}$ & $\begin{array}{l}\text { FTA Under } \\
\text { Negotiation }\end{array}$ & $\begin{array}{l}\text { The FTA aims to enhance economic links between Singapore and } \\
\text { Canada, and meet the Asia-Pacific Economic Cooperation's Bogor vision } \\
\text { of free trade and investment by } 2010 \text { for developed economies, and } 2020 \\
\text { for all economies. } \\
\text { The FTA will eliminate remaining tariffs on goods, and nontariff measures } \\
\text { and/or regulatory barriers in services. All imports into Singapore (except } \\
\text { beer, stout, and samsoo liquor) enjoy duty-free status, while Canada } \\
\text { maintains significant duties on products (such as cotton apparel and } \\
\text { ships) for which Singapore has strong domestic capability. Canada wants } \\
\text { to remove regulatory barriers (such as requirements on citizenship or } \\
\text { residency, licensing or registration, local partners, and ownership or } \\
\text { management on trade in services), to increase exports in professional, } \\
\text { telecommunications, financial, transport, and environmental services. } \\
\text { On investment, the FTA will provide more certainty and predictability, } \\
\text { enabling Canadian firms better access to the Singapore market, which } \\
\text { maintains foreign ownership restrictions by way of investment ceilings in } \\
\text { key sectors, including financial services and energy. }\end{array}$ \\
\hline $\begin{array}{l}\text { China-India } \\
\text { Regional Trading } \\
\text { Arrangement }\end{array}$ & FTA Proposed & $\begin{array}{l}\text { In June 2003, India and the People's Republic of China (PRC) agreed to } \\
\text { set-up a Joint Study Group (JSG) to expand trade and economic } \\
\text { cooperation between the two countries. The JSG was tasked to present a } \\
\text { report and recommendation on comprehensive trade and economic } \\
\text { cooperation. } \\
\text { On } 21 \text { March 2005, the report of the India-China JSG on Comprehensive } \\
\text { Trade and Economic Cooperation was finalized. It recommended a China- } \\
\text { India Regional Trading Arrangement, covering trade in goods and } \\
\text { services, investments, identified common ground for trade and investment } \\
\text { promotion and facilitation, and proposed measures for the promotion of } \\
\text { economic cooperation in identified sectors. The JSG also recommended } \\
\text { the appointment of a Joint Task Force to study in detail the feasibility and } \\
\text { benefits of the regional trading arrangement. }\end{array}$ \\
\hline $\begin{array}{l}\text { India-Korea } \\
\text { Comprehensive } \\
\text { Economic } \\
\text { Partnership } \\
\text { Agreement }\end{array}$ & $\begin{array}{l}\text { FTA Under } \\
\text { Negotiation }\end{array}$ & $\begin{array}{l}\text { In October 2004, India and the Republic of Korea established a Joint } \\
\text { Study Group (JSG) to examine the feasibility of a Comprehensive } \\
\text { Economic Partnership Agreement (CEPA) that covers trade in goods and } \\
\text { services, investment, and other areas of economic cooperation. The JSG } \\
\text { met on } 27-28 \text { January } 2005 \text {, where both parties signed its terms of } \\
\text { reference. On } 5 \text { January 2006, the JSG Report was finalized and signed } \\
\text { by both parties. The report recommended the (i) participation of India and } \\
\text { Korea into a CEPA and (ii) the creation of a Joint Task Force to work on } \\
\text { developing a CEPA for completion within a reasonable period of time. }\end{array}$ \\
\hline $\begin{array}{l}\text { India- } \\
\text { Singapore } \\
\text { Comprehensive } \\
\text { Economic } \\
\text { Cooperation } \\
\text { Agreement }\end{array}$ & $\begin{array}{l}\text { FTA Under } \\
\text { Implementation }\end{array}$ & $\begin{array}{l}\text { It covers trade in goods and services, including financial services, } \\
\text { investment, customs procedures, movement of natural persons, } \\
\text { intellectual property, and an improved agreement on double taxation. }\end{array}$ \\
\hline $\begin{array}{l}\text { India-Thailand Free } \\
\text { Trade Area }\end{array}$ & $\begin{array}{l}\text { Framework } \\
\text { Agreement } \\
\text { Signed/FTA } \\
\text { Under }\end{array}$ & $\begin{array}{l}\text { The FTA signed in } 2003 \text { covers trade in goods and services, investments, } \\
\text { and cooperation in areas such as agriculture, tourism, and construction. } \\
\text { Its objectives are to (i) create favorable conditions for greater economic } \\
\text { cooperation and the promotion of fair competition; and (ii) progressively }\end{array}$ \\
\hline
\end{tabular}

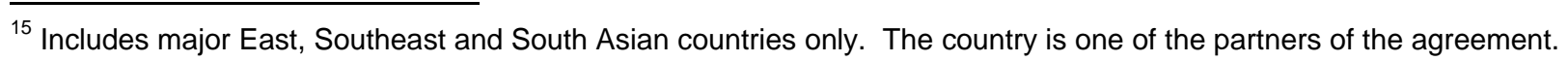




\begin{tabular}{|c|c|c|}
\hline Initiatives & Status & Description \\
\hline & Negotiation & $\begin{array}{l}\text { liberalize and remove barriers to trade, facilitating trade in goods and } \\
\text { services, and building a transparent, liberal, and enabling investment } \\
\text { climate. }\end{array}$ \\
\hline $\begin{array}{l}\text { India-Sri Lanka } \\
\text { Free Trade } \\
\text { Agreement }\end{array}$ & $\begin{array}{l}\text { FTA Under } \\
\text { Implementation }\end{array}$ & $\begin{array}{l}\text { FTA was signed in } 1998 \text { and full implementation took into effect in } 2000 . \\
\text { The objective is to establish of a Free Trade Area through complete or } \\
\text { phased elimination of tariffs. The FTA does not remove all tariffs on all } \\
\text { goods at once. Negative Lists to protect national interests of both } \\
\text { countries. The Rules of Origin (ROO) criteria to ensure a minimum local } \\
\text { content. Adequate safety clauses to protect domestic and national } \\
\text { interests of both countries. }\end{array}$ \\
\hline $\begin{array}{l}\text { Japan-Brunei Free } \\
\text { Trade Agreement }\end{array}$ & $\begin{array}{l}\text { FTA Under } \\
\text { Negotiation }\end{array}$ & $\begin{array}{l}\text { During the negotiations, Tokyo and Bandar Seri Begawan discussed } \\
\text { issues such as trade in goods, rules of origin, customs procedures, } \\
\text { services trade, investment, business facilitation measures and Japan's } \\
\text { cooperation programs for Brunei. }\end{array}$ \\
\hline $\begin{array}{l}\text { Japan-India } \\
\text { Economic } \\
\text { Partnership } \\
\text { Agreement }\end{array}$ & FTA Proposed & $\begin{array}{l}\text { On } 29 \text { November 2004, Japan and India agreed to establish a } \\
\text { Japan-India Joint Study Group (JSG) for a Comprehensive Study to serve } \\
\text { as a framework for reviewing their economic relationship. The agreement } \\
\text { was reiterated on } 6 \text { January } 2005 \text { in a Foreign Ministers' Meeting. On } 29 \\
\text { April } 2005 \text {, both parties directed the JSG to submit a report within a year, } \\
\text { focusing on requirements for a comprehensive expansion of trade in } \\
\text { goods and services, investment flows, and other areas of economic } \\
\text { cooperation. }\end{array}$ \\
\hline $\begin{array}{l}\text { Japan- Indonesia } \\
\text { Economic } \\
\text { Partnership } \\
\text { Agreement }\end{array}$ & $\begin{array}{l}\text { FTA Under } \\
\text { Negotiation }\end{array}$ & $\begin{array}{l}\text { On } 24 \text { June } 2003 \text {, Japan and Indonesia agreed to explore the possibility } \\
\text { of a bilateral economic partnership agreement, the scope of which } \\
\text { included liberalization of trade in goods, services, and investment, rules of } \\
\text { origin, movement of natural persons, government procurement, } \\
\text { competition policy, as well as areas of bilateral cooperation. } \\
\\
\text { On } 16 \text { December } 2004 \text {, both parties agreed to launch a Joint Study Group } \\
\text { (JSG) to explore the future of economic partnership. The JSG met three } \\
\text { times in early } 2005 \text { to assess the feasibility of a free trade agreement } \\
\text { (FTA) and to give recommendations on whether or not to start } \\
\text { negotiations. In June 2005, Japan and Indonesia signed an agreement to } \\
\text { start official negotiations on an FTA. In July } 2005 \text {, senior officials met to } \\
\text { initiate the first round of talks, agreeing on the modalities for further and } \\
\text { more substantive negotiations. }\end{array}$ \\
\hline $\begin{array}{l}\text { Japan-Korea Free } \\
\text { Trade Agreement } \\
\text { (JKFTA) }\end{array}$ & $\begin{array}{l}\text { FTA Under } \\
\text { Negotiation }\end{array}$ & $\begin{array}{l}\text { The Japan-Korea Free Trade Agreement (JKFTA) is a comprehensive } \\
\text { free trade agreement to expand trade and investment between the two } \\
\text { countries. It covers trade in goods and services, investment, customs } \\
\text { procedures, movement of natural persons, intellectual property rights, } \\
\text { government procurement, competition policies, and cooperation in } \\
\text { tourism. } \\
\text { JKFTA will also strengthen financial cooperation and crisis-aversion } \\
\text { through the establishment of a bilateral currency swap exchange } \\
\text { mechanism and utilization of regional bonds issued in Asian currencies. }\end{array}$ \\
\hline $\begin{array}{l}\text { Japan-Malaysia } \\
\text { Economic } \\
\text { Partnership } \\
\text { Agreement } \\
\text { (JMEPA) }\end{array}$ & FTA Signed & $\begin{array}{l}\text { The scope of JMEPA includes trade in goods and services, investment, } \\
\text { customs procedures, movement of natural persons, intellectual property, } \\
\text { competition policies, and bilateral cooperation in the fields of agriculture, } \\
\text { forestry, fisheries and commodities, education and human resource } \\
\text { development, information and communications technology, science and } \\
\text { technology, small and medium enterprises, tourism, and environment. }\end{array}$ \\
\hline $\begin{array}{l}\text { Japan-Mexico } \\
\text { Economic } \\
\text { Partnership } \\
\text { Agreement }\end{array}$ & $\begin{array}{l}\text { FTA Under } \\
\text { Implementation }\end{array}$ & $\begin{array}{l}\text { Japan and Mexico signed a bilateral free trade agreement in September } \\
2004 \text {. It took effect in April 2005. The accord is designed to phase out } \\
\text { almost all import tariffs between the two countries from } 2005 \text { to } 2014 \text {. The } \\
\text { pact is the first comprehensive free trade agreement that Japan has } \\
\text { signed with any country and in which the opening of the market for }\end{array}$ \\
\hline
\end{tabular}




\begin{tabular}{|c|c|c|}
\hline Initiatives & Status & Description \\
\hline & & $\begin{array}{l}\text { agricultural products is a key provision. In addition to the trade of goods, } \\
\text { the agreement includes provisions concerning services, investment, } \\
\text { coordination of competition policies, improvements to the business } \\
\text { environment, the training of human resources, and support for small- and } \\
\text { medium-sized enterprises. As such, it goes far beyond a simple FTA and } \\
\text { is being described as an economic partnership agreement. In the } \\
\text { agreement between Japan and Mexico, the two countries will eliminate } \\
\text { tariffs on almost all industrial products within } 10 \text { years. In certain areas } \\
\text { (electronics, household electric appliances, capital goods, and } \\
\text { automobiles), tariffs will be eliminated immediately. }\end{array}$ \\
\hline $\begin{array}{l}\text { Japan-Philippines } \\
\text { Economic } \\
\text { Partnership } \\
\text { Agreement } \\
\text { (JPEPA) }\end{array}$ & FTA Signed & $\begin{array}{l}\text { In November 2004, after five rounds of talks, both parties agreed in } \\
\text { principle on the major elements of the JPEPA. These included trade in } \\
\text { goods and services, investment, customs procedures, movement of } \\
\text { natural persons, cooperation, intellectual property rights, competition } \\
\text { policies, mutual recognition, and the business environment. } \\
\text { Japan and the Philippines will also promote bilateral cooperation in nine } \\
\text { fields, i.e., human resource development, financial services, information } \\
\text { and communications technology, energy and environment, trade and } \\
\text { investment promotion, small- and medium-scale enterprises, tourism, and } \\
\text { transportation. }\end{array}$ \\
\hline $\begin{array}{l}\text { Japan-Singapore } \\
\text { Economic } \\
\text { Agreement for a } \\
\text { New-Age } \\
\text { Partnership }\end{array}$ & $\begin{array}{l}\text { FTA Under } \\
\text { Implementation }\end{array}$ & $\begin{array}{l}\text { The objective of the Agreement is to promote greater flow of goods, } \\
\text { people, services, and capital, and facilitate economic partnership and } \\
\text { links in financial services, information and communication technology, and } \\
\text { human resource development. It covers (i) liberalization and facilitation of } \\
\text { trade in goods and services, investment, rules of origin, customs } \\
\text { procedures, a mutual recognition agreement, movement of natural } \\
\text { persons, and government procurement; and (ii) partnership and } \\
\text { cooperation in customs procedures, paperless trading, intellectual } \\
\text { property, competition policy, financial services, information and } \\
\text { communication technology, science and technology, human capital } \\
\text { management and development, trade and investment promotion, } \\
\text { development of small- and medium-scale enterprises, broadcasting, and } \\
\text { tourism. }\end{array}$ \\
\hline $\begin{array}{l}\text { Japan-Thailand } \\
\text { Economic } \\
\text { Partnership } \\
\text { Agreement } \\
\text { (JTEPA) }\end{array}$ & $\begin{array}{l}\text { FTA Under } \\
\text { Negotiation }\end{array}$ & $\begin{array}{l}\text { The scope of JTEPA includes trade in goods and services, investment, } \\
\text { customs procedures, movement of natural persons, intellectual property } \\
\text { rights, competition policies, mutual recognition, and the business climate. }\end{array}$ \\
\hline $\begin{array}{l}\text { Japan-Vietnam } \\
\text { Free Trade } \\
\text { Agreement }\end{array}$ & $\begin{array}{l}\text { FTA Under } \\
\text { Negotiation }\end{array}$ & $\begin{array}{l}\text { The Japan-Viet Nam Investment Agreement, with some exception, } \\
\text { guarantees national treatment and most-favored-nation treatment at the } \\
\text { stage of pre-establishment of investment, and prohibits the relevant } \\
\text { authorities from imposing requirements to conduct specific measures } \\
\text { including transfer of technology and achieving a given level of domestic } \\
\text { content (so-called "performance requirement"), that carry impeding effects } \\
\text { on investment in order to provide the rules in terms of liberalization, } \\
\text { promotion and protection of investment in a comprehensive manner. } \\
\text { The Agreement is expected to contribute to the development and } \\
\text { stabilization of the investment environment in each country and thereby } \\
\text { even further reinforce the bilateral economic relationship of the two } \\
\text { countries. }\end{array}$ \\
\hline $\begin{array}{l}\text { Korea-Canada Free } \\
\text { Trade Agreement }\end{array}$ & $\begin{array}{l}\text { FTA Under } \\
\text { Negotiation }\end{array}$ & $\begin{array}{l}\text { The FTA will cover goods (industrial products; and agricultural, livestock, } \\
\text { And fishery products) and services (finance, communications, } \\
\text { construction, and distribution), investment, government procurement, } \\
\text { intellectual property rights, and competition. }\end{array}$ \\
\hline $\begin{array}{l}\text { Korea-Chile Free } \\
\text { Trade Agreement }\end{array}$ & $\begin{array}{l}\text { FTA Under } \\
\text { Implementation }\end{array}$ & $\begin{array}{l}\text { The FTA provides for the progressive elimination of tariffs on goods from } \\
\text { both countries. The tariff elimination schedule of Korea provides for (i) a }\end{array}$ \\
\hline
\end{tabular}




\begin{tabular}{|c|c|c|}
\hline Initiatives & Status & Description \\
\hline & & $\begin{array}{l}\text { phased removal spread over } 16 \text { years; (ii) tariff elimination to begin after } \\
\text { The end of the Doha Development Agenda negotiations; (iii) liberalization } \\
\text { of tariff quotas; and (iv) liberalization over ten years on a seasonal basis. } \\
\text { Chile's offer is a phased removal over } 13 \text { years. Korea will not eliminate } \\
\text { tariffs on rice, apples, and pears, while Chile will do the same for } \\
\text { household or laundry-type washing machines, and refrigerators. } \\
\text { For trade in services and investment, the agreement includes provisions } \\
\text { on national treatment, most-favored-nation status, losses and } \\
\text { compensation for the liberalization of trade in services and investment, } \\
\text { Subject to respective negative lists, with additional quantitative restrictions } \\
\text { imposed only on trade in services. Nevertheless, it provides for future } \\
\text { liberalization on the remaining restrictions every two years after the FTA } \\
\text { effectivity. The FTA also covers government procurement, intellectual } \\
\text { property rights, and competition policies, compensation, and performance } \\
\text { requirements. }\end{array}$ \\
\hline $\begin{array}{l}\text { Korea- Singapore } \\
\text { Free Trade } \\
\text { Agreement } \\
\text { (KSFTA) }\end{array}$ & $\begin{array}{l}\text { FTA Under } \\
\text { Implementation }\end{array}$ & $\begin{array}{l}\text { The objectives of the KSFTA are to: (i) liberalize and facilitate trade in } \\
\text { goods and services, and expand investment; (ii) establish a cooperative } \\
\text { framework for strengthening economic relations; and (iii) set-up a } \\
\text { framework for further regional and multilateral cooperation to expand and } \\
\text { enhance the benefits of this FTA throughout Asia, and encourage } \\
\text { economic integration of Asian economies. } \\
\text { The FTA covers the following areas: trade in goods, services, investment, } \\
\text { government procurement, Mutual Recognition Agreement (MRA), } \\
\text { intellectual property rights, and cooperation. }\end{array}$ \\
\hline $\begin{array}{l}\text { Korea-US Free } \\
\text { Trade Agreement }\end{array}$ & $\begin{array}{l}\text { FTA Under } \\
\text { Negotiation }\end{array}$ & $\begin{array}{l}\text { South Korea and US will begin formal talks in June aimed at forging a } \\
\text { free-trade agreement which is expected to be signed by June } 2007 \text {. }\end{array}$ \\
\hline $\begin{array}{l}\text { Malaysia- Australia } \\
\text { Free Trade } \\
\text { Agreement } \\
\text { (MAFTA) }\end{array}$ & $\begin{array}{l}\text { FTA Under } \\
\text { Negotiation }\end{array}$ & $\begin{array}{l}\text { The first round of negotiations was held on 19-20 May 2005. The parties } \\
\text { agreed on an administrative framework and a set of negotiating principles } \\
\text { and objectives to guide the negotiations. A second round was held in } \\
\text { August } 2005 \text {, and discussions covered trade in goods and services, } \\
\text { investment, trade facilitation, and the structure and content of the } \\
\text { agreement. }\end{array}$ \\
\hline $\begin{array}{l}\text { Malaysia-New } \\
\text { Zealand Free Trade } \\
\text { Agreement }\end{array}$ & $\begin{array}{l}\text { FTA Under } \\
\text { Negotiation }\end{array}$ & $\begin{array}{l}\text { On } 5 \text { September } 2004 \text {, Malaysia and New Zealand agreed to prepare } \\
\text { parallel studies on a possible bilateral free trade agreement (FTA) within } \\
\text { six months. On } 30 \text { March } 2005, \text { both parties agreed to start negotiations } \\
\text { and conclude talks by end-2005. } \\
\text { The first meeting was held on } 16-17 \text { May } 2005 \text { and discussed the } \\
\text { approach, scope, structure, and schedule of the FTA. A second meeting } \\
\text { on } 4-6 \text { July } 2005 \text { discussed the approach and modalities for trade } \\
\text { liberalization in goods, services, and investment, and cooperation to } \\
\text { facilitate and promote trade. Progress has been made across all issues. } \\
\text { In the third round of negotiations held on } 14-16 \text { September } 2005 \text {, } \\
\text { progress was made in draft chapters on goods, services, investments, } \\
\text { and cooperation activities. Moreover, discussions were made on } \\
\text { modalities for the liberalization of goods, measures to address technical } \\
\text { barriers to trade, intellectual property rights, and capacity building. } \\
\text { Negotiations are now in its final stages with the completion of the } 5^{\text {th }} \\
\text { round on } 25 \text { November } 2005 \text {. }\end{array}$ \\
\hline $\begin{array}{l}\text { Malaysia- Pakistan } \\
\text { Free Trade } \\
\text { Agreement }\end{array}$ & $\begin{array}{l}\text { FTA Under } \\
\text { Negotiation }\end{array}$ & $\begin{array}{l}\text { In February 2005, Malaysia and Pakistan agreed to negotiate a free trade } \\
\text { agreement (FTA). In the first meeting of the trade negotiating committee } \\
\text { (TNC) on } 18 \text { April 2005, it was agreed the FTA would cover liberalization } \\
\text { of trade in goods and services, investment, and economic cooperation. } \\
\text { Negotiations on goods and investment are expected to be completed by } \\
\text { end-2005. Services would be negotiated after the Sixth World Trade } \\
\text { Organization Ministerial Conference. }\end{array}$ \\
\hline
\end{tabular}




\begin{tabular}{|c|c|c|}
\hline Initiatives & Status & Description \\
\hline & & $\begin{array}{l}\text { A June } 2005 \text { meeting discussed the scope of products to be included } \\
\text { under an Early Harvest Package (EHP), the time frame, rules of origin, } \\
\text { areas to be covered under investment, and a dispute settlement } \\
\text { mechanism. } \\
\text { In the third meeting held on } 18-20 \text { July } 2005 \text {, Malaysia offered } 114 \\
\text { products covering yarn, clothing, and textile products, while Pakistan } \\
\text { offered } 125 \text { products covering electrical appliances and machinery, } \\
\text { plastics, chemical, rubber, and timber products under the EHP. } \\
\text { On } 1 \text { October 2005, Malaysia and Pakistan signed the Agreement on the } \\
\text { EHP for implementation on } 1 \text { January } 2006 \text { and shall expire upon entry } \\
\text { into force of the FTA or } 31 \text { March } 2007, \text { whichever is earlier. }\end{array}$ \\
\hline $\begin{array}{l}\text { New Zealand-China } \\
\text { Free Trade } \\
\text { Agreement }\end{array}$ & $\begin{array}{l}\text { Framework } \\
\text { Agreement } \\
\text { Signed/FTA } \\
\text { Under } \\
\text { Negotiation }\end{array}$ & $\begin{array}{l}\text { The two sides reached a consensus on the trade of products and } \\
\text { services, investment, intellectual property rights, resolution of disputes, } \\
\text { rules of origins, customs cooperation, technical barriers and other issues. } \\
\text { New Zealand was the first developed country to sign a bilateral } \\
\text { agreement with China on its accession to the World Trade Organization. It } \\
\text { was the first developed country to recognize China's status as a market } \\
\text { economy. And it was the first developed country to launch bilateral } \\
\text { negotiations with China on a free trade agreement. }\end{array}$ \\
\hline $\begin{array}{l}\text { New Zealand- } \\
\text { Singapore Closer } \\
\text { Economic } \\
\text { Partnership }\end{array}$ & $\begin{array}{l}\text { FTA Under } \\
\text { Implementation }\end{array}$ & $\begin{array}{l}\text { Its objectives are to (i) improve the efficiency and competitiveness of } \\
\text { respective goods and services sectors of New Zealand and Singapore, } \\
\text { and expand trade and investment; and (ii) support the wider liberalization } \\
\text { process in APEC and, in particular, the realization of the Bogor goals of } \\
\text { free and open trade and investment by } 2010 \text { for industrialized economies, } \\
\text { and by } 2020 \text { for developing economies. } \\
\text { The scope of the Agreement includes trade in goods and services, } \\
\text { investment in goods and services, customs procedures, government } \\
\text { procurement, and intellectual property rights. Both parties removed all } \\
\text { tariffs on goods from } 1 \text { January } 2001 \text {. Moreover, nontariff barriers are not } \\
\text { allowed to impede trade between the two countries, while export } \\
\text { subsidies on all goods, including agricultural products, are prohibited. }\end{array}$ \\
\hline $\begin{array}{l}\text { Pakistan- } \\
\text { Bangladesh Free } \\
\text { Trade Agreement }\end{array}$ & $\begin{array}{l}\text { FTA Under } \\
\text { Negotiation }\end{array}$ & $\begin{array}{l}\text { A bilateral meeting between the Commerce Minister of Pakistan and his } \\
\text { Bangladeshi counterpart was held at Dhaka in pursuance of the decisions } \\
\text { taken to restart the FTA negotiations during the recent visit of the Prime } \\
\text { Minister of Bangladesh to Pakistan. } \\
\text { The bilateral FTA would be based on the principle of reciprocity and would } \\
\text { go beyond the tariff concessions provided under the SAFTA agreement. } \\
\text { Both the Commerce Ministers agreed to put the bilateral initiatives on fast } \\
\text { track and to conclude the negotiations at the technical level by end July, } \\
2006 \text { and to complete the procedures and constitutional requirement by } \\
\text { September, } 2006 \text { in order to operationalize the bilateral FTA. } \\
\text { Moreover, the first meeting of the SAFTA Committee of Experts (COE) } \\
\text { was held in Dhaka on 18-19 April, 2006. In accordance with the agenda } \\
\text { of the two-day meeting, the delegates from member countries deliberated } \\
\text { on issues related to the implementation of SAFTA agreement including } \\
\text { technical aspects and modalities. A working group was formed which met } \\
\text { on the sidelines of SAFTA COE meeting to work out Terms of Reference } \\
\text { for the Sub-Group on Non Tariff Barriers. }\end{array}$ \\
\hline $\begin{array}{l}\text { Pakistan-Indonesia } \\
\text { Free Trade } \\
\text { Agreement }\end{array}$ & $\begin{array}{l}\text { Framework } \\
\text { Agreement } \\
\text { Signed/FTA } \\
\text { Under }\end{array}$ & $\begin{array}{l}\text { Pakistan and Indonesia signed a comprehensive economic framework } \\
\text { agreement for expanding economic cooperation and trade between the } \\
\text { two countries in } 2005 \text {. }\end{array}$ \\
\hline
\end{tabular}




\begin{tabular}{|c|c|c|}
\hline Initiatives & Status & Description \\
\hline & Negotiation & $\begin{array}{l}\text { The agreement was signed in the presence of President Pervez } \\
\text { Musharraf and his Indonesian counterpart Susilo Bambang Yudhoyono. } \\
\text { The two leaders expressed willingness to conclude a free trade } \\
\text { agreement and start formal talks immediately. } \\
\text { A joint statement issued after the formal talks said both the nations had } \\
\text { welcomed the signing of the pact and expressed their willingness to sign a } \\
\text { free trade agreement (FTA) soon. To ensure a fast track strategy towards } \\
\text { this goal, it was decided that an agreement on preferential trade } \\
\text { agreement (PTA) would be negotiated in the near future by the ministries } \\
\text { concerned of the two countries. } \\
\text { The two leaders noted that bilateral trade was steadily growing and was } \\
\text { expected to exceed } \$ 600 \text { million in } 2005 \text {. They also welcomed a two-way } \\
\text { trend of new investments. } \\
\text { However, it was agreed that there remained considerable untapped } \\
\text { potential to diversify trade and further increase investments, taking } \\
\text { advantage of the existing complementarities. Both the sides agreed to } \\
\text { take measures to elevate further the bilateral trade from the current levels } \\
\text { to at least } \$ 1 \text { billion in the near future. }\end{array}$ \\
\hline $\begin{array}{l}\text { Pakistan- } \\
\text { Singapore Free } \\
\text { Trade Agreement }\end{array}$ & $\begin{array}{l}\text { FTA Under } \\
\text { Negotiation }\end{array}$ & $\begin{array}{l}\text { Pakistan proposed a free trade agreement (FTA) with Singapore in June } \\
\text { 2003. An exploratory FTA meeting in February } 2005 \text { discussed the } \\
\text { possible scope and timeframe for negotiations. The first round of } \\
\text { negotiations were held on } 24-26 \text { August } 2005 \text {, focusing on key issues } \\
\text { involving trade in goods and services, investment, rules of origin, and } \\
\text { legal chapters of the proposed FTA. }\end{array}$ \\
\hline $\begin{array}{l}\text { Pakistan-Sri Lanka } \\
\text { Free Trade } \\
\text { Agreement }\end{array}$ & $\begin{array}{l}\text { FTA Under } \\
\text { Implementation }\end{array}$ & $\begin{array}{l}\text { The Pakistan-Sri Lanka Free Trade Agreement (FTA) has come into force } \\
\text { from June 12, 2005, marking a new stage in regional economic } \\
\text { integration. } \\
\text { Covering } 100 \text { per cent duty concession offered by Pakistan on } 206 \\
\text { products and by Sri Lanka on } 102 \text { products (under the six-digit HS } \\
\text { classification), the FTA has been implemented a little more than five years } \\
\text { after the India-Sri Lanka FTA was ushered in. } \\
\text { Items in the zero duty list of Pakistan (subject to application of the } \\
\text { mutually agreed rules of origin) include frozen fish, vegetables, spices, } \\
\text { fruits/juices, polymers of vinyl chloride in primary forms, natural rubber } \\
\text { (excluding latex), raw silk, tanned/crust skins, wool, some varieties of } \\
\text { paper and board, carpet and floor covering, non-alloy aluminium, iron and } \\
\text { steel products and toys/dolls. } \\
\text { Sri Lanka's nil duty items under the FTA include chickpeas, dates, } \\
\text { oranges, benzene, toluene, apparel and clothing accessories, ball } \\
\text { bearing, penicillin/streptomycin/tetracycline and their derivatives and } \\
\text { vacuum flasks (excluding glass inners). } \\
\text { The negative ("no concession") list of both countries is much longer. } \\
\text { Pakistan has named } 540 \text { items in its negative list, including dairy } \\
\text { products, green/black tea, animal/vegetable oils and fats, } \\
\text { cigarettes/tobacco, liquor, certain categories of paints/varnishes, } \\
\text { polymers, yarn (excluding sewing thread) and iron/non-alloy steel. Sri } \\
\text { Lanka's negative list includes } 697 \text { items. } \\
\text { Among these are bovine meat, some marine products, yogurt, curled milk, } \\
\text { vegetables, raw sugar, bread, petrol/kerosene, polymers and tyres. } \\
\text { The agreement provides for safeguard actions in the case of serious } \\
\text { injury and threat of serious injury to domestic industry and "critical } \\
\text { circumstances" arising from preferential imports. } \\
\text { It says the two countries shall not increase existing "para tariffs" (namely, }\end{array}$ \\
\hline
\end{tabular}




\begin{tabular}{|c|c|c|}
\hline Initiatives & Status & Description \\
\hline & & $\begin{array}{l}\text { border charges and fees other than tariffs levied solely on imports) or } \\
\text { introduce new ones without mutual consent. } \\
\text { The FTA specifically provides that the two parties honour the principle of } \\
\text { national treatment (non- discrimination against imports vis-a-vis } \\
\text { domestically produced goods) embodied in the World Trade Organisation } \\
\text { (WTO). }\end{array}$ \\
\hline $\begin{array}{l}\text { People's Republic } \\
\text { of China (PRC)- } \\
\text { Australia Free } \\
\text { Trade Agreement }\end{array}$ & $\begin{array}{l}\text { Framework } \\
\text { Agreement } \\
\text { Signed/FTA } \\
\text { Under } \\
\text { Negotiation }\end{array}$ & $\begin{array}{l}\text { On } 24 \text { October 2003, Australia and the People's Republic of China signed } \\
\text { a Trade and Economic Framework to boost trade and investment. The } \\
\text { framework commits both countries to prepare a free trade agreement } \\
\text { (FTA) joint feasibility study. On } 18 \text { April 2005, they agreed to start } \\
\text { negotiations following the study's completion in March } 2005 \text {. Based on } \\
\text { study recommendations, the FTA is expected to remove tariffs on most } \\
\text { trade and ensure that nontariff barriers will not negate the benefits of tariff } \\
\text { removal. Services liberalization was recommended, focusing on removal } \\
\text { of barriers with wide sectoral coverage. The FTA is also expected to } \\
\text { eliminate or reduce existing restrictions on foreign investment, enhance } \\
\text { transparency and streamline investment regulations and applications, and } \\
\text { provide stronger protection to investors of both parties. } \\
\text { Two rounds of negotiations have been held in May and August 2005. The } \\
\text { FTA will be comprehensive, covering goods (including agriculture) and } \\
\text { services, investment, customs facilitation, intellectual property rights, } \\
\text { transparency, capacity building, government procurement, competition } \\
\text { policies, and economic cooperation. }\end{array}$ \\
\hline $\begin{array}{l}\text { People's Republic } \\
\text { of China (PRC)- } \\
\text { Chile Free Trade } \\
\text { Agreement }\end{array}$ & FTA Signed & $\begin{array}{l}\text { China and Chile's Free Trade Agreement became effective } 1 \text { October } \\
2006 \text {. This agreement establishes immediate reduction of tariffs on } 92 \% \\
\text { of Chilean exports to China. For China, this percentage amounts to } 50 \% \\
\text { of its current trade. } \\
\text { The treaty also considers tariff reductions after 1, 5, and } 10 \text { years for } \\
\text { Chilean products accessing China, and terms of } 1,2,5 \text {, and } 10 \text { years for } \\
\text { Chinese exports to Chile. Product exclusions for 1\% of Chilean exports } \\
\text { and } 3 \% \text { of Chinese shipments to our country were agreed to protect } \\
\text { certain sensible sectors. } \\
\text { The Chilean products considered by China for immediate and after five- } \\
\text { year tariff reductions that will benefit the most of the FTA include copper } \\
\text { and other minerals, vegetables, fish oils, poultry, fresh cherries, fresh } \\
\text { peaches and fresh nectarines, wood panels, smoked salmon, cheese, } \\
\text { canned peaches, chocolates, and tomato paste. Meanwhile, it was agreed } \\
\text { that the tariff reduction for products that had been declared by China as } \\
\text { highly vulnerable, such as fresh and frozen salmon, grapes and apples, } \\
\text { World go down from } 15 \text { to } 10 \text { years. } \\
\text { On the other hand, the Chilean negotiators achieved that products which } \\
\text { are sensible for Chile such as cements, some chemicals, surgical gloves, } \\
\text { certain areas of the textile and clothing sector, remain within the } 10-y e a r \\
\text { category. Exceptions also considered agricultural products subject to } \\
\text { price bands (wheat, flour, and sugar), tires, some areas of textiles and } \\
\text { clothing, metallurgical products, and household appliances. Chile } \\
\text { excluded from the Free Trade Agreement } 152 \text { products, all considered } \\
\text { sensible for our production sectors. } \\
\text { The Chinese products that will have immediate access to the Chilean } \\
\text { market include machinery, computers, vehicles, DVD's, and printers, } \\
\text { among others. }\end{array}$ \\
\hline $\begin{array}{l}\text { People's Republic } \\
\text { of China (PRC)- } \\
\text { Pakistan Free } \\
\text { Trade Agreement }\end{array}$ & $\begin{array}{l}\text { FTA Under } \\
\text { Negotiation }\end{array}$ & $\begin{array}{l}\text { Pakistan and China are expected to launch the much awaited free trade } \\
\text { regime under the Early Harvest Programme (EHP) from } 1 \text { January } 2006 \text {. } \\
\text { The trade under the EHP includes arrangement on the basis of mutually } \\
\text { agreed lists of items. The first list includes fruits and vegetables and }\end{array}$ \\
\hline
\end{tabular}




\begin{tabular}{|c|c|c|}
\hline Initiatives & Status & Description \\
\hline & & $\begin{array}{l}\text { marble. Both nations will reduce tariff on these items to zero gradually, but } \\
\text { not later than end of } 2007 \text {. The second list includes home textiles, towels, } \\
\text { chewing gum, cotton fabric, cutlery, surgical goods and sports goods for } \\
\text { Pakistan and machinery and chemicals for China. These items would also } \\
\text { be zero-rated gradually. Items in the third list provide tariff concession on } \\
\text { the basis of margin of preference. According to the EHP, more than } 3,000 \\
\text { categories of products will have zero tariff from } 1 \text { January, } 2006.486 \\
\text { categories of Chinese goods exported to Pakistan will enjoy the zero-tariff } \\
\text { treatment, mainly vegetables, fruit, stone materials, textile machinery and } \\
\text { organic chemical products. } \\
\text { Meanwhile, China will give zero-tariff status to } 769 \text { categories of goods } \\
\text { imported from Pakistan, mainly vegetables, fruit, stone materials, cotton } \\
\text { fabrics and man-made fabrics. For those products with lower tariffs, China } \\
\text { will cut its tariffs by } 27 \% \text { on } 1,671 \text { kinds of products from Pakistan, and } \\
\text { Pakistan will cut tariffs by an average range of } 22 \% \text { on } 575 \text { kinds of } \\
\text { products from China (posted } 12 \text { December } 2005 \text { in Bilateral Org } \\
\text { par } \text { ). }\end{array}$ \\
\hline $\begin{array}{l}\text { People's Republic } \\
\text { of China (PRC)- } \\
\text { Thailand Free } \\
\text { Trade Agreement }\end{array}$ & $\begin{array}{l}\text { FTA Under } \\
\text { Implementation }\end{array}$ & $\begin{array}{l}\text { Thailand and China have begun a joint meeting to strengthen ties and } \\
\text { wipe out trade obstacles, hoping to increase bilateral trade under the free } \\
\text { trade area (FTA) framework. } \\
\text { The meeting focused on the import and export of fruits and vegetables of } \\
\text { the two countries. The Sino-Thai trade under the FTA had increased to } \\
\text { more than US } \$ 8 \text { billion in the first ten months of this year, from US } \$ 7.12 \\
\text { billion since October } 1,2003 \text {. Cooperation and mutual visits by } \\
\text { delegations of each side would help boost bilateral trade and investment } \\
\text { and ease possible misunderstanding of the agreement and obstacles to } \\
\text { trade. It will also help raise the number of tourists to no more than } 4 \\
\text { million in the period. }\end{array}$ \\
\hline $\begin{array}{l}\text { Singapore- } \\
\text { Australia Free } \\
\text { Trade Agreement } \\
\text { (SAFTA) }\end{array}$ & $\begin{array}{l}\text { FTA Under } \\
\text { Implementation }\end{array}$ & $\begin{array}{l}\text { Both parties removed tariffs on all goods from SAFTA's effectivity. For } \\
\text { Australia, this added tariff-free entry of beer and stout (other Australian } \\
\text { products were already duty free). They also agreed not to use export } \\
\text { subsidies or safeguard measures against one another. } \\
\text { SAFTA's services framework requires both countries to treat each other's } \\
\text { service suppliers on the same terms, i.e., apply national treatment, and } \\
\text { remove quantitative or other market access restrictions on service } \\
\text { suppliers, using a negative list approach. In addition, both countries } \\
\text { agreed that there would be no additional trade barriers in these sectors. } \\
\text { SAFTA covers professional services, transportation services, distribution } \\
\text { services, tourism, environmental services, and recreational, cultural, and } \\
\text { sporting services. } \\
\text { Liberalization of banking licenses and the insurance and securities } \\
\text { markets in Singapore have given Australian financial service investors } \\
\text { greater business confidence. In addition, restrictions on the number of } \\
\text { wholesale banking licenses available to Australian banks have been } \\
\text { eased over time. Australia has committed its current regime on market } \\
\text { access policies with respect to all major areas of financial services. } \\
\text { Moreover, Australia will allow financial institutions in Singapore to offer } \\
\text { new services. } \\
\text { Investment liberalization covers the manufacturing and service sectors, as } \\
\text { well as the various stages of the investment process. Traditional methods } \\
\text { are used, but also include a review of commitments, and access to state } \\
\text { dispute settlement. } \\
\text { SAFTA also provides for a more open and predictable business }\end{array}$ \\
\hline
\end{tabular}

16 http://www.bilaterals.org/article.php3?id_article=3386. 


\begin{tabular}{|c|c|c|}
\hline Initiatives & Status & Description \\
\hline & & $\begin{array}{l}\text { environment in competition policies, government procurement, intellectual } \\
\text { property rights, e-commerce, customs procedures, and business travel. }\end{array}$ \\
\hline $\begin{array}{l}\text { Singapore- Egypt } \\
\text { Free Trade } \\
\text { Agreement }\end{array}$ & $\begin{array}{l}\text { FTA Under } \\
\text { Negotiation }\end{array}$ & $\begin{array}{l}\text { Prime Minister Goh Chok Tong visited Egypt from } 11 \text { to } 14 \text { February } \\
2004 \text {, at the invitation of His Excellency, Atef Ebied, Prime Minister of the } \\
\text { Republic of Egypt. During the visit, the leaders agreed to launch } \\
\text { negotiations to conclude a Free Trade Agreement. }\end{array}$ \\
\hline $\begin{array}{l}\text { Singapore- Jordan } \\
\text { Free Trade } \\
\text { Agreement (SJFTA) }\end{array}$ & $\begin{array}{l}\text { FTA Under } \\
\text { Implementation }\end{array}$ & $\begin{array}{l}\text { Launched in October 2003, negotiations for the Singapore-Jordan Free } \\
\text { Trade Agreement (SJFTA) and the Singapore-Jordan Bilateral Investment } \\
\text { Treaty (BIT) were concluded on } 29 \text { April 2004. The two agreements were } \\
\text { subsequently signed by then Minister of State for Foreign Affairs and } \\
\text { Trade and Industry, Mr Raymond Lim, and Deputy Prime Minister and } \\
\text { Minister for Industry and Trade, H.E. Mohammad Halaiqa, on } 16 \text { May } \\
2004 \text { at the sidelines of the World Economic Forum in Amman, Jordan. } \\
\text { On } 22 \text { August 2005, the SJFTA and the BIT came into force after both } \\
\text { countries had completed their legal and administrative procedures to } \\
\text { implement the agreements. } \\
\text { The SJFTA is Singapore's first FTA with a country in the Middle East and } \\
\text { Jordan's first FTA with a country in Asia. It aims to provide an institutional } \\
\text { platform for increasing economic engagement between Singapore and } \\
\text { Jordan. The SJFTA and the BIT are comprehensive and forward looking. } \\
\text { They cover a broad range of economic activities, which will facilitate the } \\
\text { flow of goods, services and investments between the two countries and } \\
\text { beyond. } \\
\text { The SJFTA and the BIT form part of a broader Framework on Closer } \\
\text { Economic Partnership between Singapore and Jordan, which also } \\
\text { includes a Technical Support Agreement signed in October } 2003 \text { and } \\
\text { Memorandum of Understanding in Cultural and Tourism Cooperation } \\
\text { signed during the Official Visit of Prime Minister Goh Chok Tong to Jordan } \\
\text { in February 2004. These agreements will serve to deepen and broaden } \\
\text { our links with Jordan and the Middle East region. }\end{array}$ \\
\hline $\begin{array}{l}\text { Singapore- Kuwait } \\
\text { Free Trade } \\
\text { Agreement }\end{array}$ & $\begin{array}{l}\text { FTA Under } \\
\text { Negotiation }\end{array}$ & $\begin{array}{l}\text { Prime Minister of Kuwait, His Highness Sheikh Sabah Al-Ahmed Al-Jaber } \\
\text { Al-Sabah, made an official visit to Singapore on } 19-20 \text { July } 2004 \text {. His } \\
\text { Highness and Mr Goh Chok Tong, then-Prime Minister of Singapore, met } \\
\text { on } 19 \text { July } 2004 \text { and agreed to pursue a bilateral FTA between Kuwait } \\
\text { and Singapore. } \\
\text { Subsequently, when Minister of State (T\&l) Heng Chee How led a } \\
\text { delegation to visit Kuwait in October } 2004 \text {, a preliminary FTA discussion } \\
\text { meeting between the Chief Negotiators was held at the sidelines. Both } \\
\text { sides aim to conclude the FTA negotiations within } 3 \text { to } 4 \text { rounds. }\end{array}$ \\
\hline $\begin{array}{l}\text { Singapore- Mexico } \\
\text { Free Trade } \\
\text { Agreement }\end{array}$ & $\begin{array}{l}\text { FTA Under } \\
\text { Negotiation }\end{array}$ & $\begin{array}{l}\text { Negotiations for the Mexico-Singapore FTA started in Jul } 2000.6 \text { rounds } \\
\text { of trade talks have taken place to date, along with a series of road-shows } \\
\text { in Mexico to drum up support among the Mexican business community. }\end{array}$ \\
\hline $\begin{array}{l}\text { Singapore- Panama } \\
\text { Free Trade } \\
\text { Agreement }\end{array}$ & FTA Signed & $\begin{array}{l}\text { The Panama-Singapore Free Trade Agreement entered into force on } 24 \\
\text { July } 2006 \text {. The agreement was signed on } 1 \text { March } 2006 \text { by Singapore's } \\
\text { Minister of State for Trade and Industry and for Education Chan Soo Sen } \\
\text { and Panamanian Vice-Minister for Commerce and Industry Ms Carmen } \\
\text { Gisela Vergara. Negotiations for the Agreement were first launched on } 17 \\
\text { Feb } 04 \text { in Singapore and were substantially concluded after three rounds. } \\
\text { The Panama-Singapore FTA is a broad-based and comprehensive } \\
\text { agreement, covering issues such as trade in goods and services, customs } \\
\text { procedures, financial services, investment, telecommunications, e- } \\
\text { commerce, competition policy and government procurement. It also } \\
\text { provides for collaboration between Panama and Singapore in areas such } \\
\text { as investment promotion and science and technology. }\end{array}$ \\
\hline
\end{tabular}




\begin{tabular}{|c|c|c|}
\hline Initiatives & Status & Description \\
\hline & & $\begin{array}{l}\text { Aside from enhancing economic links between Panama and Singapore, } \\
\text { the Panama-Singapore FTA will also help to deepen Singapore's } \\
\text { engagement with the Latin American region as a whole. The Panama- } \\
\text { Singapore FTA is our first bilateral FTA with a Latin American country. In } \\
\text { 2005, Singapore signed a plurilateral FTA - the Trans-Pacific Strategic } \\
\text { Economic Partnership Agreement - with Brunei, Chile and New Zealand. }\end{array}$ \\
\hline $\begin{array}{l}\text { Singapore- Peru } \\
\text { Free Trade } \\
\text { Agreement }\end{array}$ & $\begin{array}{l}\text { FTA Under } \\
\text { Negotiation }\end{array}$ & $\begin{array}{l}\text { Peru and Singapore announced the launch of negotiations for a bilateral } \\
\text { free trade agreement (FTA) on } 19 \text { Nov } 04 \text {. The announcement was made } \\
\text { following a meeting between Singapore Prime Minister Lee Hsien Loong } \\
\text { and Peruvian President Alejandro Toledo Manrique at the sidelines of the } \\
\text { APEC Economic Leaders Meeting in Santiago, Chile. Negotiations for the } \\
\text { FTA are targeted to commence in } 2006 \text { and are expected to be completed } \\
\text { within a year. }\end{array}$ \\
\hline $\begin{array}{l}\text { Singapore- Qatar } \\
\text { Free Trade } \\
\text { Agreement }\end{array}$ & $\begin{array}{l}\text { FTA Under } \\
\text { Negotiation }\end{array}$ & $\begin{array}{l}\text { During his visit to Qatar on } 1 \text { April 2004, then Minister (T\&l) George Yeo } \\
\text { called on H.E. Sheikh Mohammed bin Ahmed bin Jassim Al-Thani, } \\
\text { Minister of Economy and Commerce, State of Qatar. The subject of } \\
\text { concluding a bilateral FTA was discussed at the call. Both trade ministers } \\
\text { agreed that an FTA would bring bilateral relations to new heights and } \\
\text { serve as a platform for enhanced trade and economic relations. } \\
\text { Subsequently, preliminary discussions on the FTA were held between the } \\
\text { Chief Negotiators in mid-September 2004, after which the first round of } \\
\text { FTA negotiations was held in Singapore from } 22-23 \text { December 2004, in } \\
\text { conjunction with Minister Al-Thani's visit to Singapore on } 20-23 \text { December } \\
2004 \text {. }\end{array}$ \\
\hline $\begin{array}{l}\text { Thailand- Australia } \\
\text { Free Trade } \\
\text { Agreement } \\
\text { (TAFTA) }\end{array}$ & $\begin{array}{l}\text { FTA Under } \\
\text { Implementation }\end{array}$ & $\begin{array}{l}\text { TAFTA aims to fulfill Asia-Pacific Economic Cooperation's Bogor goals of } \\
\text { free trade and investment by } 2010 \text { for industrialized economies, and by } \\
2020 \text { for developing countries. }\end{array}$ \\
\hline $\begin{array}{l}\text { Thailand-New } \\
\text { Zealand Closer } \\
\text { Economic } \\
\text { Partnership } \\
\text { Agreement }\end{array}$ & $\begin{array}{l}\text { FTA Under } \\
\text { Implementation }\end{array}$ & $\begin{array}{l}\text { The Thailand-New Zealand Closer Economic Partnership Agreement was } \\
\text { signed on } 19 \text { April } 2005 \text { and became effective on } 1 \text { July } 2005 \text { to (i) } \\
\text { liberalize trade and investment and create favorable conditions for } \\
\text { increased trade and investment flows; (ii) support wider liberalization and } \\
\text { the facilitation process within Asia-Pacific Economic Cooperation; (iii) } \\
\text { build on World Trade Organization commitments; and, (iv) improve the } \\
\text { efficiency and competitiveness of trade by promoting fair competition. }\end{array}$ \\
\hline $\begin{array}{l}\text { Thailand- Bahrain } \\
\text { Free Trade } \\
\text { Agreement }\end{array}$ & $\begin{array}{l}\text { Framework } \\
\text { Agreement } \\
\text { Signed/FTA } \\
\text { Under } \\
\text { Negotiation }\end{array}$ & $\begin{array}{l}\text { The Thailand-Bahrain Closer Economic Partnership Agreement was } \\
\text { signed on } 29 \text { December } 2002 \text {. Areas of economic cooperation includes all } \\
\text { areas, particularly energy, finance, including banking, Islamic banking, } \\
\text { insurance and joint ventures, manufacturing, trade and investment, } \\
\text { promotion and facilitation, mobility of business people, transportation, } \\
\text { fisheries, information and communication technology, customs procedures } \\
\text { and quarantine, and standards and specifications. }\end{array}$ \\
\hline $\begin{array}{l}\text { US-Malaysia Free } \\
\text { Trade Agreement }\end{array}$ & $\begin{array}{l}\text { FTA Under } \\
\text { Negotiation }\end{array}$ & $\begin{array}{l}\text { The US-Malaysia free trade agreement can be concluded by year-end as } \\
\text { major benefits far outweigh any negative impacts, according to US-based } \\
\text { Trade Adjustment Assistance Coalition (TAAC) executive director Howard } \\
\text { Rosen. } \\
\text { The sectoral issues in the US-Malaysia FTA are agriculture (palm oil and } \\
\text { rice); services (higher education, tourism and travel, financial services and } \\
\text { professional and business services); and the automotive market. } \\
\text { The Ministry of International Trade and Industry (Miti) said in a statement } \\
\text { on June } 26 \text { that Malaysia has requested for early duty elimination for } \\
\text { textiles and garments, rubber and wood, ceramics, electrical and } \\
\text { electronics and agricultural products, with current duties ranging from } 5 \% \\
\text { to } 32 \% \text {, at the recent FTA negotiations. "Tariffs on non-sensitive } \\
\text { products have been proposed to be eliminated faster while sensitive } \\
\text { products be given flexibility," it said, adding that the first round of the talks, }\end{array}$ \\
\hline
\end{tabular}




\begin{tabular}{|l|l|l|}
\hline \multicolumn{1}{|c|}{ Initiatives } & \multicolumn{1}{|c|}{ Status } & $\begin{array}{l}\text { Description } \\
\text { held on June 12 to 15, covered 18 issues. } \\
\text { However, Miti said discussions were still at preliminary stages for areas } \\
\text { such as environment, competition policy and intellectual property rights. } \\
\text { It added that Malaysia was seeking longer time frames for liberalisation of } \\
\text { sensitive products and services sectors, and flexibility to undertake policy } \\
\text { measures for its developmental needs. }\end{array}$ \\
\hline $\begin{array}{l}\text { US-Singapore Free } \\
\text { Trade Agreement }\end{array}$ & $\begin{array}{l}\text { FTA Under } \\
\text { Implementation }\end{array}$ & $\begin{array}{l}\text { The objectives of the FTA are to (i) secure trade liberalization and an } \\
\text { outward-looking approach to trade and investment; (ii) achieve the Asia- } \\
\text { Pacific Economic Cooperation's Bogor goals of free and open trade and } \\
\text { investment; (iii) facilitate bilateral trade through removal or reduction of } \\
\text { barriers to the movement of goods between the parties; (iv) promote } \\
\text { competition and transparency; (v) expand trade in services; and (vi) } \\
\text { pursue liberalization in a manner consistent with the protection and } \\
\text { enhancement of the environment. }\end{array}$ \\
\hline $\begin{array}{l}\text { US-Thailand Free } \\
\text { Trade Agreement }\end{array}$ & $\begin{array}{l}\text { FTA Under } \\
\text { Negotiation }\end{array}$ & $\begin{array}{l}\text { Membership in the World Trade Organization and a Trade and Investment } \\
\text { Framework Agreement (TIFA) are needed to start FTA negotiations with } \\
\text { the US. A TIFA was signed on 23 October 2002, with the negotiation } \\
\text { timetable and coverage. The FTA is comprehensive and covers topics } \\
\text { such as market access. The US and Thailand started negotiations on a } \\
\text { comprehensive bilateral free trade agreement in June 2004 for industrial } \\
\text { products, textiles and apparel, agricultural products, technical barriers to } \\
\text { trade, cross border services, financial services, investment, } \\
\text { telecommunication, competition policy, labor, and environment. }\end{array}$ \\
\hline
\end{tabular}

Sources: Asia Regional Information Center (ARIC) website, Asian Development Bank ${ }^{17}$ and Bilateral Org $^{18}$.

\section{Table 4: Major Subregional Free Trade Agreements in Asia ${ }^{19}$ under Negotiation/Implementation}

\begin{tabular}{|c|c|c|}
\hline Initiatives & Status & Description \\
\hline $\begin{array}{l}\text { ASEAN Free Trade } \\
\text { Area (AFTA) }\end{array}$ & $\begin{array}{l}\text { FTA Under } \\
\text { Implementation }\end{array}$ & $\begin{array}{l}\text { The Agreement on a Common Effective Preferential Tariff Scheme for the } \\
\text { Association of Southeast Asian Nations (ASEAN) was signed in January } \\
1992 \text { and became effective in January } 1993 \text {. } \\
\text { It aims to integrate ASEAN economies into a single productive region, } \\
\text { capitalizing on a regional market of } 500 \text { million people. } \\
\text { The ASEAN Free Trade Area (AFTA) covers all manufactured and } \\
\text { agricultural products, services, and investment. } \\
\text { With the signing of the Protocol to amend the CEPT-AFTA Agreement on } \\
30 \text { January } 2003 \text {, ASEAN- } 6 \text { is committed to eliminate tariffs on } 60 \% \text { of the } \\
\text { products in their inclusion list. } \\
\text { An ASEAN Economic Community, characterized by a freer flow of goods, } \\
\text { services, investment, labor, and capital, is targeted by } 2020 \text {. }\end{array}$ \\
\hline $\begin{array}{l}\text { ASEAN- Australia } \\
\text { and New Zealand } \\
\text { Free Trade } \\
\text { Agreement }\end{array}$ & $\begin{array}{l}\text { FTA Under } \\
\text { Negotiation }\end{array}$ & $\begin{array}{l}\text { It aims to deepen the level of economic integration between Australia, } \\
\text { New Zealand, and the Association of Southeast Asian Nations (ASEAN) } \\
\text { through a work program focused on trade facilitation and capacity } \\
\text { building. } \\
\text { The FTA will be comprehensive, covering trade in goods and services, }\end{array}$ \\
\hline
\end{tabular}

\footnotetext{
17 http:/www.aric.adb.org/regionalcooperation/integration_initiatives.asp?s=1\&ss=3.

${ }_{18}$ Bilateral Org website: http://www.bilaterals.org/article.php3?id_article=3386.

19 Includes major East, Southeast and South Asian countries only. The country is one of the partners of the agreement.
} 


\begin{tabular}{|c|c|c|}
\hline Initiatives & Status & Description \\
\hline & & $\begin{array}{l}\text { and investment. It aims to further deepen economic integration through } \\
\text { progressive elimination of all forms of trade and investment barriers, and } \\
\text { through trade and investment facilitation and other economic } \\
\text { cooperation. }\end{array}$ \\
\hline $\begin{array}{l}\text { ASEAN-China } \\
\text { Free Trade Area } \\
\text { (ACFTA) }\end{array}$ & $\begin{array}{l}\text { FTA Under } \\
\text { Implementation }\end{array}$ & $\begin{array}{l}\text { The Framework Agreement provides an Early Harvest Program (EHP) } \\
\text { consisting of unprocessed agricultural products and specific products } \\
\text { agreed upon between individual ASEAN countries and the PRC. } \\
\text { Aside from trade and investment, cooperation has broadened and } \\
\text { deepened between ASEAN member countries and the PRC to include } \\
\text { cooperation on infrastructure as well as on information and } \\
\text { communications technology. }\end{array}$ \\
\hline $\begin{array}{l}\text { ASEAN-EU Free } \\
\text { Trade Agreement }\end{array}$ & FTA Proposed & $\begin{array}{l}\text { The Trans-Regional EU-ASEAN Trade Initiative (TREATI) was proposed } \\
\text { by the European Commission in July } 2003 \text { as a framework for dialogue } \\
\text { and regulatory cooperation to enhance European Union (EU) trade } \\
\text { relations with the Association of Southeast Asian Nations (ASEAN). } \\
\text { TREATI is a precursor for an eventual ASEAN-EU Free Trade Agreement } \\
\text { (FTA). A joint feasibility study on ASEAN-EU Economic Cooperation, } \\
\text { including a possible FTA, has started. }\end{array}$ \\
\hline $\begin{array}{l}\text { ASEAN-India } \\
\text { Regional Trade and } \\
\text { Investment Area }\end{array}$ & $\begin{array}{l}\text { Framework } \\
\text { Agreement } \\
\text { Signed/FTA } \\
\text { Under } \\
\text { Negotiation }\end{array}$ & $\begin{array}{l}\text { ASEAN and India signed a Framework Agreement for Comprehensive } \\
\text { Economic Cooperation at the Second ASEAN-India Summit in } 2003 . \\
\text { Under the Framework Agreement, the parties agree to establish an } \\
\text { ASEAN-India Regional Trade and Investment Area (RTIA), including a } \\
\text { free trade area. An ASEAN-India Trade Negotiation Committee was } \\
\text { established in March } 2004 \text { to negotiate implementation of the provisions } \\
\text { of the Framework Agreement. }\end{array}$ \\
\hline $\begin{array}{l}\text { ASEAN-Japan } \\
\text { Comprehensive } \\
\text { Economic } \\
\text { Partnership } \\
\text { (AJCEP) }\end{array}$ & $\begin{array}{l}\text { Framework } \\
\text { Agreement } \\
\text { Signed/FTA } \\
\text { Under } \\
\text { Negotiation }\end{array}$ & $\begin{array}{l}\text { The framework for Association of Southeast Asian Nations } \\
\text { (ASEAN)-Japan Comprehensive Economic Partnership (AJCEP) was } \\
\text { signed on } 8 \text { October 2003. Negotiations on the AJCEP Agreement were } \\
\text { launched in April 2005, to conclude after two years. Implementation of the } \\
\text { AJCEP, including a free trade agreement, is expected to be completed by } \\
2012 \text {. }\end{array}$ \\
\hline $\begin{array}{l}\text { ASEAN-Korea Free } \\
\text { Trade Area } \\
\text { (AKFTA) }\end{array}$ & $\begin{array}{l}\text { Framework } \\
\text { Agreement } \\
\text { Signed/FTA } \\
\text { Under } \\
\text { Negotiation }\end{array}$ & $\begin{array}{l}\text { AKFTA's objective is to move toward deeper economic integration } \\
\text { between the two regions, through progressive elimination of all barriers to } \\
\text { increased trade and investment. AKFTA will maintain flexibility, allowing } \\
\text { special or differential treatment in areas such as technical assistance and } \\
\text { capacity building, especially for newer ASEAN members to compensate } \\
\text { for different levels of development. This approach will enable these } \\
\text { economies to fully participate and take advantage of AKFTA's benefits. } \\
\text { The scope of AKFTA includes trade liberalization and facilitation, areas for } \\
\text { cooperation, and consultations and dispute settlement. }\end{array}$ \\
\hline BANGKOK & $\begin{array}{l}\text { Bangkok } \\
\text { Agreement }\end{array}$ & $\begin{array}{l}\text { BANGKOK agreement entered into force in } 1976 \text { as a preferential trading } \\
\text { arrangement. The five original participating states are Bangladesh, India, } \\
\text { Republic of Korea, Laos and Sri Lanka. People's Republic of China } \\
\text { acceded on } 12 \text { April } 2001 \text { and has been implementing concessions under } \\
\text { the agreement since } 1 \text { January } 2002 \text {. }\end{array}$ \\
\hline $\begin{array}{l}\text { BIMSTEC Free } \\
\text { Trade Area }\end{array}$ & $\begin{array}{l}\text { Framework } \\
\text { Agreement } \\
\text { Signed/FTA } \\
\text { Under } \\
\text { Negotiation }\end{array}$ & $\begin{array}{l}\text { BIMSTEC adopted a framework agreement for an FTA to be implemented } \\
\text { within } 10 \text { years at its first Summit held in Bangkok in July } 2004 \text {. The } \\
\text { BIMSTEC FTA will cover trade in goods and services, investment, and } \\
\text { cooperation in sectors such as technology, transportation and } \\
\text { communication, energy, tourism, and fisheries. The Framework } \\
\text { Agreement also provides for the liberalization of trade in services and } \\
\text { investments, both with substantial sectoral coverage through a positive list } \\
\text { approach. }\end{array}$ \\
\hline
\end{tabular}




\begin{tabular}{|c|c|c|}
\hline Initiatives & Status & Description \\
\hline $\begin{array}{l}\text { East Asia Free } \\
\text { Trade Area } \\
\text { (EAFTA) }\end{array}$ & FTA Proposed & $\begin{array}{l}\text { The establishment of an East Asia Free Trade Area (EAFTA) is one of the } \\
\text { nine long-term measures, which were proposed by the East Asia Study } \\
\text { Group (EASG) and adopted by ASEAN+3 Summit in November } 2002 \text {. At } \\
\text { the eight ASEAN+3 Summit on } 29 \text { November } 2004 \text {, the leaders requested } \\
\text { the ASEAN+3 Economic Ministers to formulate an expert group to study } \\
\text { the feasibility of the EAFTA. }\end{array}$ \\
\hline $\begin{array}{l}\text { Japan-Gulf } \\
\text { Cooperation } \\
\text { Council Free Trade } \\
\text { Agreement }\end{array}$ & $\begin{array}{l}\text { FTA Under } \\
\text { Negotiation }\end{array}$ & $\begin{array}{l}\text { Japan and the Gulf Cooperation Council, or GCC, held the first round of } \\
\text { talks on a free trade agreement in Tokyo. The GCC includes Bahrain, } \\
\text { Saudi Arabia, Kuwait, Oman, Qatar and the United Arab Emirates. } \\
\text { Officials will exchange views on trade in goods and services, aimed at } \\
\text { reaching an early agreement. No date has been set for a conclusion of } \\
\text { an agreement. The GCC was formed in } 1981 \text { to devise a unified political, } \\
\text { economic and military policy. }\end{array}$ \\
\hline $\begin{array}{l}\text { Korea-European } \\
\text { Free Trade } \\
\text { Association Free } \\
\text { Trade Agreement }\end{array}$ & $\begin{array}{l}\text { FTA Under } \\
\text { Implementation }\end{array}$ & $\begin{array}{l}\text { The Free Trade Agreement between the EFTA States and Korea was } \\
\text { signed in Hong Kong (Hong Kong, China) on } 15 \text { December 2005. The } \\
\text { Agreement entered into force on } 1 \text { September } 2006 \text {. The Agreement } \\
\text { covers all major areas of trade relations including trade in goods, trade in } \\
\text { services, government procurement, competition and intellectual property. } \\
\text { A Joint Committee is established for the supervision of the Agreement, } \\
\text { and a chapter provides for dispute settlement procedures. Moreover, the } \\
\text { EFTA States and Korea concluded bilateral agreements on basic } \\
\text { agricultural products. An agreement on investment has been concluded } \\
\text { between Korea, on the one hand, and Iceland, Liechtenstein and } \\
\text { Switzerland, on the other, as well. }\end{array}$ \\
\hline $\begin{array}{l}\text { Kunming Economic } \\
\text { Cooperation } \\
\text { Initiative }\end{array}$ & & $\begin{array}{l}\text { The cooperation covers Bangladesh, India, Myanmar, and the People's } \\
\text { Republic of China. The first sub-regional economic conference among } \\
\text { these four countries was held in 1999. The Kunming Declaration that } \\
\text { called for intensified economic cooperation based on the principles of } \\
\text { mutual benefit, equality, and sustainable development was issued. This } \\
\text { cooperation has been institutionalized, with the conference held every } \\
\text { four years. }\end{array}$ \\
\hline $\begin{array}{l}\text { Pakistan-Gulf } \\
\text { Cooperation } \\
\text { Council Free Trade } \\
\text { Agreement }\end{array}$ & $\begin{array}{l}\text { Framework } \\
\text { Agreement } \\
\text { Signed/FTA } \\
\text { Under } \\
\text { Negotiation }\end{array}$ & $\begin{array}{l}\text { Pakistan and the GCC will sign a Free Trade Agreement (FTA) by the end } \\
\text { of } 2006 \text { to remove existing tariff and non-tariff barriers which are creating } \\
\text { obstacles in the bilateral trade and to boost foreign direct investment, joint } \\
\text { ventures and greater economic cooperation. }\end{array}$ \\
\hline $\begin{array}{l}\text { People's Republic } \\
\text { of China (PRC)- } \\
\text { Gulf Cooperation } \\
\text { Council Free Trade } \\
\text { Agreement }\end{array}$ & $\begin{array}{l}\text { FTA Under } \\
\text { Negotiation }\end{array}$ & $\begin{array}{l}\text { On April } 3 \text { and 4, 2006, the 4th Working Group Meeting of China-GCC } \\
\text { FTA Negotiation was held in Muscat, Capital of Oman. Chinese } \\
\text { delegation, including officials from the Ministry of Commerce, Ministry of } \\
\text { Agriculture, China's Customs and General Administration of Quality } \\
\text { Supervision, Inspection and Quarantine of China, took part in the } \\
\text { negotiation. And during the negotiation, the two sides consulted deeply } \\
\text { issues of market access, rules of origin, laws concerning goods trade, } \\
\text { trade relief, TBT, SPS and draft text of FTA, and obtained active progress, } \\
\text { further narrowed the different opinions on market access, came to a } \\
\text { consensus in aspects of rules of origin, TBT and SPS, and exchanged } \\
\text { views on draft text of an agreement on goods trade in the Area. }\end{array}$ \\
\hline $\begin{array}{l}\text { South Asian Free } \\
\text { Trade Area } \\
\text { (SAFTA) }\end{array}$ & $\begin{array}{l}\text { FTA Under } \\
\text { Implementation }\end{array}$ & $\begin{array}{l}\text { It was designed primarily as a first step towards the transition to a South } \\
\text { Asian Free Trade Area (SAFTA), leading subsequently towards a customs } \\
\text { union, common market, and economic union. } \\
\text { SAFTA provides a framework creating a free trade zone in Bangladesh, } \\
\text { Bhutan, India, Maldives, Nepal, Pakistan, and Sri Lanka and aims to } \\
\text { further promote and enhance trade and economic cooperation among the } \\
\text { group. }\end{array}$ \\
\hline $\begin{array}{l}\text { Thailand-EFTA } \\
\text { Free Trade }\end{array}$ & $\begin{array}{l}\text { FTA Under } \\
\text { Negotiation }\end{array}$ & $\begin{array}{l}\text { On October 15th, the EFTA countries completed the first full-fledged } \\
\text { round of negotiations with the aim to complete a comprehensive Free }\end{array}$ \\
\hline
\end{tabular}




\begin{tabular}{|l|l|l|}
\hline \multicolumn{1}{|c|}{ Initiatives } & \multicolumn{1}{|c|}{ Status } & \multicolumn{1}{c|}{ Description } \\
\hline Agreement & Trade Agreement (FTA) in 2006. \\
& $\begin{array}{l}\text { The launch of the free trade negotiations follows the exploratory meeting } \\
\text { held in Reykjavik, Iceland in May, 2005. In Phuket, the Parties discussed } \\
\text { tariff elimination for industrial goods, the opening up of markets for } \\
\text { agricultural goods, as well as the liberalisation of trade in services, } \\
\text { investments, public procurement and the protection of intellectual property } \\
\text { rights. } \\
\text { An FTA is expected to be highly beneficial to both parties, which have few } \\
\text { goods that are in direct competition. }\end{array}$ \\
\hline
\end{tabular}

Sources: Asia Regional Information Center (ARIC) website, Asian Development Bank ${ }^{20}$ and Bilateral Org ${ }^{21}$.

${ }^{20}$ http:/www.aric.adb.org/regionalcooperation/integration_initiatives.asp?s=1\&ss=3.

${ }^{21}$ Bilateral Org website: http://www.bilaterals.org/article.php3?id_article=3386. 


\section{CESifo Working Paper Series}

(for full list see www.cesifo-group.de)

1796 Louis Eeckhoudt, Béatrice Rey and Harris Schlesinger, A Good Sign for Multivariate Risk Taking, September 2006

1797 Dominique M. Gross and Nicolas Schmitt, Why do Low- and High-Skill Workers Migrate? Flow Evidence from France, September 2006

1798 Dan Bernhardt, Stefan Krasa and Mattias Polborn, Political Polarization and the Electoral Effects of Media Bias, September 2006

1799 Pierre Pestieau and Motohiro Sato, Estate Taxation with Both Accidental and Planned Bequests, September 2006

1800 Øystein Foros and Hans Jarle Kind, Do Slotting Allowances Harm Retail Competition?, September 2006

1801 Tobias Lindhe and Jan Södersten, The Equity Trap, the Cost of Capital and the Firm's Growth Path, September 2006

1802 Wolfgang Buchholz, Richard Cornes and Wolfgang Peters, Existence, Uniqueness and Some Comparative Statics for Ratio- and Lindahl Equilibria: New Wine in Old Bottles, September 2006

1803 Jan Schnellenbach, Lars P. Feld and Christoph Schaltegger, The Impact of Referendums on the Centralisation of Public Goods Provision: A Political Economy Approach, September 2006

1804 David-Jan Jansen and Jakob de Haan, Does ECB Communication Help in Predicting its Interest Rate Decisions?, September 2006

1805 Jerome L. Stein, United States Current Account Deficits: A Stochastic Optimal Control Analysis, September 2006

1806 Friedrich Schneider, Shadow Economies and Corruption all over the World: What do we really Know?, September 2006

1807 Joerg Lingens and Klaus Waelde, Pareto-Improving Unemployment Policies, September 2006

1808 Axel Dreher, Jan-Egbert Sturm and James Raymond Vreeland, Does Membership on the UN Security Council Influence IMF Decisions? Evidence from Panel Data, September 2006

1809 Prabir De, Regional Trade in Northeast Asia: Why do Trade Costs Matter?, September 2006 
1810 Antonis Adam and Thomas Moutos, A Politico-Economic Analysis of Minimum Wages and Wage Subsidies, September 2006

1811 Guglielmo Maria Caporale and Christoph Hanck, Cointegration Tests of PPP: Do they also Exhibit Erratic Behaviour?, September 2006

1812 Robert S. Chirinko and Hisham Foad, Noise vs. News in Equity Returns, September 2006

1813 Oliver Huelsewig, Eric Mayer and Timo Wollmershaeuser, Bank Behavior and the Cost Channel of Monetary Transmission, September 2006

1814 Michael S. Michael, Are Migration Policies that Induce Skilled (Unskilled) Migration Beneficial (Harmful) for the Host Country?, September 2006

1815 Eytan Sheshinski, Optimum Commodity Taxation in Pooling Equilibria, October 2006

1816 Gottfried Haber and Reinhard Neck, Sustainability of Austrian Public Debt: A Political Economy Perspective, October 2006

1817 Thiess Buettner, Michael Overesch, Ulrich Schreiber and Georg Wamser, The Impact of Thin-Capitalization Rules on Multinationals' Financing and Investment Decisions, October 2006

1818 Eric O’N. Fisher and Sharon L. May, Relativity in Trade Theory: Towards a Solution to the Mystery of Missing Trade, October 2006

1819 Junichi Minagawa and Thorsten Upmann, Labor Supply and the Demand for Child Care: An Intertemporal Approach, October 2006

1820 Jan K. Brueckner and Raquel Girvin, Airport Noise Regulation, Airline Service Quality, and Social Welfare, October 2006

1821 Sijbren Cnossen, Alcohol Taxation and Regulation in the European Union, October 2006

1822 Frederick van der Ploeg, Sustainable Social Spending in a Greying Economy with Stagnant Public Services: Baumol’s Cost Disease Revisited, October 2006

1823 Steven Brakman, Harry Garretsen and Charles van Marrewijk, Cross-Border Mergers \& Acquisitions: The Facts as a Guide for International Economics, October 2006

1824 J. Atsu Amegashie, A Psychological Game with Interdependent Preference Types, October 2006

1825 Kurt R. Brekke, Ingrid Koenigbauer and Odd Rune Straume, Reference Pricing of Pharmaceuticals, October 2006

1826 Sean Holly, M. Hashem Pesaran and Takashi Yamagata, A Spatio-Temporal Model of House Prices in the US, October 2006 
1827 Margarita Katsimi and Thomas Moutos, Inequality and the US Import Demand Function, October 2006

1828 Eytan Sheshinski, Longevity and Aggregate Savings, October 2006

1829 Momi Dahan and Udi Nisan, Low Take-up Rates: The Role of Information, October 2006

1830 Dieter Urban, Multilateral Investment Agreement in a Political Equilibrium, October 2006

1831 Jan Bouckaert and Hans Degryse, Opt In Versus Opt Out: A Free-Entry Analysis of Privacy Policies, October 2006

1832 Wolfram F. Richter, Taxing Human Capital Efficiently: The Double Dividend of Taxing Non-qualified Labour more Heavily than Qualified Labour, October 2006

1833 Alberto Chong and Mark Gradstein, Who's Afraid of Foreign Aid? The Donors' Perspective, October 2006

1834 Dirk Schindler, Optimal Income Taxation with a Risky Asset - The Triple Income Tax, October 2006

1835 Andy Snell and Jonathan P. Thomas, Labour Contracts, Equal Treatment and WageUnemployment Dynamics, October 2006

1836 Peter Backé and Cezary Wójcik, Catching-up and Credit Booms in Central and Eastern European EU Member States and Acceding Countries: An Interpretation within the New Neoclassical Synthesis Framework, October 2006

1837 Lars P. Feld, Justina A.V. Fischer and Gebhard Kirchgaessner, The Effect of Direct Democracy on Income Redistribution: Evidence for Switzerland, October 2006

1838 Michael Rauscher, Voluntary Emission Reductions, Social Rewards, and Environmental Policy, November 2006

1839 Vincent Vicard, Trade, Conflicts, and Political Integration: the Regional Interplays, November 2006

1840 Erkki Koskela and Mikko Puhakka, Stability and Dynamics in an Overlapping Generations Economy under Flexible Wage Negotiation and Capital Accumulation, November 2006

1841 Thiess Buettner, Michael Overesch, Ulrich Schreiber and Georg Wamser, Taxation and Capital Structure Choice - Evidence from a Panel of German Multinationals, November 2006

1842 Guglielmo Maria Caporale and Alexandros Kontonikas, The Euro and Inflation Uncertainty in the European Monetary Union, November 2006 
1843 Jan K. Brueckner and Ann G. Largey, Social Interaction and Urban Sprawl, November 2006

1844 Eytan Sheshinski, Differentiated Annuities in a Pooling Equilibrium, November 2006

1845 Marc Suhrcke and Dieter Urban, Are Cardiovascular Diseases Bad for Economic Growth?, November 2006

1846 Sam Bucovetsky and Andreas Haufler, Preferential Tax Regimes with Asymmetric Countries, November 2006

1847 Luca Anderlini, Leonardo Felli and Andrew Postlewaite, Should Courts always Enforce what Contracting Parties Write?, November 2006

1848 Katharina Sailer, Searching the eBay Marketplace, November 2006

1849 Paul De Grauwe and Pablo Rovira Kaltwasser, A Behavioral Finance Model of the Exchange Rate with Many Forecasting Rules, November 2006

1850 Doina Maria Radulescu and Michael Stimmelmayr, ACE vs. CBIT: Which is Better for Investment and Welfare?, November 2006

1851 Guglielmo Maria Caporale and Mario Cerrato, Black Market and Official Exchange Rates: Long-Run Equilibrium and Short-Run Dynamics, November 2006

1852 Luca Anderlini, Leonardo Felli and Andrew Postlewaite, Active Courts and Menu Contracts, November 2006

1853 Andreas Haufler, Alexander Klemm and Guttorm Schjelderup, Economic Integration and Redistributive Taxation: A Simple Model with Ambiguous Results, November 2006

1854 S. Brock Blomberg, Thomas DeLeire and Gregory D. Hess, The (After) Life-Cycle Theory of Religious Contributions, November 2006

1855 Albert Solé-Ollé and Pilar Sorribas-Navarro, The Effects of Partisan Alignment on the Allocation of Intergovernmental Transfers. Differences-in-Differences Estimates for Spain, November 2006

1856 Biswa N. Bhattacharyay, Understanding the Latest Wave and Future Shape of Regional Trade and Cooperation Agreements in Asia, November 2006 